\title{
Transplantable Melanomas in Hamsters and Gerbils as Models for Human Melanoma. Sensitization in Melanoma Radiotherapy-From Animal Models to Clinical Trials
}

\author{
Martyna Śniegocka ${ }^{1, *(1)}$, Ewa Podgórska ${ }^{1, *}$, Przemysław M. Płonka ${ }^{1}$ (D), Martyna Elas ${ }^{1(\mathbb{D})}$ \\ Bożena Romanowska-Dixon ${ }^{2}$, Małgorzata Szczygieł ${ }^{1}$, Michał A. Żmijewski ${ }^{3}$, \\ Mirosława Cichorek ${ }^{4}$, Anna Markiewicz ${ }^{2}$, Anna A. Brożyna ${ }^{5,6}$, Andrzej T. Słominski ${ }^{6,7, *(1)}$ \\ and Krystyna Urbańska ${ }^{1, *}$ \\ 1 Department of Biophysics, Faculty of Biochemistry, Biophysics and Biotechnology, \\ Jagiellonian University in Kraków, 31-007 Kraków, Poland; przemyslaw.plonka@uj.edu.pl (P.M.P.); \\ martyna.elas@uj.edu.pl (M.E.); gosia.szczygiel@uj.edu.pl (M.S.) \\ 2 Department of Ophthalmology and Ocular Oncology, Medical College of Jagiellonian University in Kraków, \\ 31-007 Kraków, Poland; bozena.romanowska-dixon@uj.edu.pl (B.R.-D.); annamarkiewicz@interia.pl (A.M.) \\ 3 Department of Histology, Medical University of Gdansk, 80-210 Gdańsk, Poland; \\ mzmijewski@gumed.edu.pl \\ 4 Department of Embryology, Medical University of Gdansk, 80-210 Gdańsk, Poland; cichorek@gumed.edu.pl \\ 5 Department of Tumor Pathology and Pathomorphology, Faculty of Health Sciences, Nicolaus Copernicus \\ University Collegium Medicum in Bydgoszcz, Oncology Centre-Prof. Franciszek Łukaszczyk Memorial \\ Hospital, 85-796 Bydgoszcz, Poland; anna.brozyna@cm.umk.pl \\ 6 Department of Dermatology, Comprehensive Cancer Center Cancer Chemoprevention Program, \\ University of Alabama at Birmingham, Birmingham, AL 35294, USA \\ 7 VA Medical Center, Birmingham, AL 35294, USA \\ * Correspondence: martyna.sniegocka@doctoral.uj.edu.pl (M.Ś.); Ewa.podgorska@doctoral.uj.edu.pl (E.P.); \\ aslominski@uabmc.edu (A.T.S.); krystyna.urbanska@uj.edu.pl (K.U.); Tel.: +001-205-934-5188 (A.T.S.); \\ +48-12-664-6153 (K.U.)
}

Received: 29 December 2017; Accepted: 28 March 2018; Published: 1 April 2018

\begin{abstract}
The focus of the present review is to investigate the role of melanin in the radioprotection of melanoma and attempts to sensitize tumors to radiation by inhibiting melanogenesis. Early studies showed radical scavenging, oxygen consumption and adsorption as mechanisms of melanin radioprotection. Experimental models of melanoma in hamsters and in gerbils are described as well as their use in biochemical and radiobiological studies, including a spontaneously metastasizing ocular model. Some results from in vitro studies on the inhibition of melanogenesis are presented as well as radio-chelation therapy in experimental and clinical settings. In contrast to cutaneous melanoma, uveal melanoma is very successfully treated with radiation, both using photon and proton beams. We point out that the presence or lack of melanin pigmentation should be considered, when choosing therapeutic options, and that both the experimental and clinical data suggest that melanin could be a target for radiosensitizing melanoma cells to increase efficacy of radiotherapy against melanoma.
\end{abstract}

Keywords: melanoma; melanins; Bomirski hamster melanoma; ocular melanoma; human melanoma; X-rays; neutrons; proton beam irradiation; radio-chelation therapy; radio-photo-therapy; chemo-radiotherapy; tumor vessels 


\section{Introduction}

Malignant melanoma is one of the most notorious and deadly human tumors. It has been known since at least the fifth century B.C., when it was mentioned by Hippocrates of Cos [1]. Its most characteristic biological feature is the ability to produce and store melanin [1], which in turn is also responsible for important features of the tumor, making it resistant to many modes of therapy [2].

There are numerous papers exploring the models of murine melanomas. The present review intends to summarize the work on less popular animal models in melanoma research, i.e., Syrian golden hamsters (Mesocricetus auratus Waterhouse 1839) and Mongolian gerbils (Meriones unguiculatus Milne-Edwards 1867). These laboratory animals and their melanomas reveal quite unique features which in some aspects make them akin to human melanomas. The research has been carried out for over 50 years in several research centers, mainly in Poland and USA, largely using models developed locally in Gdansk and Krakow (Bomirski hamster melanoma BHM [3-6]), and gerbil melanoma Zeman UJ90 [7,8], which makes this compilation of research quite unique. A particular emphasis has been placed on radiotherapy and melanin as factors determining the effectiveness of melanoma therapy.

\section{Melanin Functions and Their Radioprotective Role in Melanoma}

Melanoma originates from melanocytes, which are responsible for generating melanin [9]. This polymer is produced in melanosomes, organelles coming from lysosomal lineage, and transferred to other cells in the mammalian skin, mainly to keratinocytes [10]. This transfer can be disturbed in melanomas, which may either store large amounts of melanin in the cytoplasm or secrete it to the environment $[8,11,12]$. Consequently, it leads to intra- or extracellular accumulation of melanin or its precursors, which can be toxic $[13,14]$. During the process of melanogenesis, such intermediates are generated, which may accelerate the induction of secondary mutations in melanoma cells [15]. This can be one of the reasons for which a melanotic phenotype in late-stage melanoma is connected with poor prognosis [16]. Moreover, the signaling pathways responsible for melanin synthesis are partially common with those involved in neoplastic transformation [17-20]. As a result, in a melanogenically active cell, every mutation in genes coding regulatory factors, such as the cAMP response element-binding protein (CREB) [21], PI3K/p70 [22], c-KIT [23], (neuroblastoma RAS viral oncogene homolog) (NRAS) [24,25], or (serine/threonine-protein kinase B-raf) (BRAF), becomes automatically expressed [26-28], manifesting itself in the pigment phenotype, and in gaining neoplastic features at the same time [29].

On the other hand, the generation of melanin itself is protective for the body and the cell. The production of melanin is of a clearly adaptive value. Thus, it provides animal camouflage, and it protects the body against different type of radiation including UV protection spectrum [30,31]. Being a macromolecule of amorphous structure, it often reveals properties of inorganic rather than organic substances [32]. Its spectrum of absorption resembles inorganic material [33], as devoid of characteristic maxima of absorption, and monotonously decreases from UV towards longer waves, and for infra-red irradiation melanin becomes almost transparent [33,34]. This broadening of spectrum is responsible for its brown to black coloration, and also makes it a good photoprotector because of a high efficiency of conversion of the absorbed irradiation into heat [32,34]. Melanin contains numerous carboxylic groups of various degrees of protonation, and quinone/hydroquinone groups of various degrees of oxidation, containing also semiquinones responsible for its paramagnetic properties $[32,35,36]$. All that makes melanin a powerful buffer able to reversibly protonate, and a redox-buffer able to reversibly oxidate and recombine with external free radicals (e.g., produced by radio- or photolysis of water in the cytoplasm [37,38]). The complicated, irregular inner structure makes melanin an efficient ion-exchange resin able to reversibly adsorb metal cations (zinc, calcium, iron, copper, manganese, etc.), organic compounds, gases, and water $[32,36,39,40]$.

Despite its resistance to acid hydrolysis, melanin undergoes degradation in the body, probably with the engagement of the reduced nicotinamide adenine dinucleotide phosphate (NADPH)-dependent oxidoreductases (NOX), and/or the visible light and UV [41,42]. The substances 
adsorbed in the past may be released back in the process of melanin degradation, and made active with a delay, some of them (e.g., iron or copper) being photochemically or redox-active themselves. This is responsible for melanin toxicity and phototoxicity, stronger for pheomelanin than for eumelanin $[19,38,43-45]$.

The high accumulation of paramagnetic centers in the molecules of melanin was suggested to enable this polymer to interact with radiation-induced free radical species as a radical scavenger. The comparative studies on the sensitivity of animal cells to low-linear energy transfer (LET) radiation support the view that melanin content of the cell can affect its radiation response [46]. Polymethyl methacrylate (PMM) mixed with melanin in different concentrations was irradiated with 75 Gy to study the X-ray-generated free radical signal. It was demonstrated that oxygen-centered polymer signal was decreasing faster in the presence of increasing concentrations of synthetic melanin [47], directly showing the protective role of melanin addition (see Figure 1). Similar reactions can be found if dry collagen is used as a matrix instead of PMM [47].

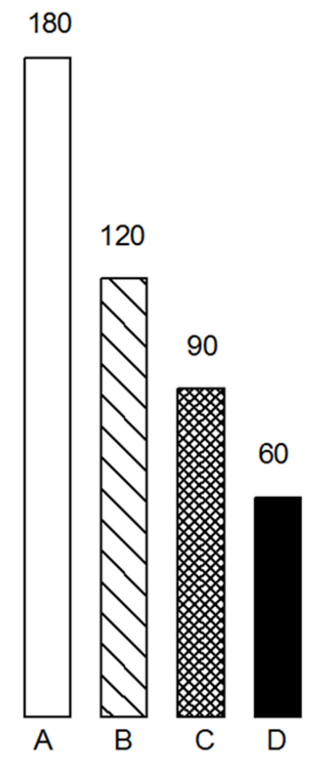

Figure 1. The presence of melanin in polymethyl methacrylate (PMM) inhibits the decay of free radical signal, induced by X-rays. A-450 mg of pure PMM, B-450 $\mathrm{mg}$ of PMM with $2 \mathrm{mg}$ of melanin, C $-450 \mathrm{mg}$ of PMM with $4 \mathrm{mg}$ of melanin, D—450 $\mathrm{mg}$ of PMM with $6 \mathrm{mg}$ of melanin. Figure based on [47]. Copyright 1975 IAEA.

In addition to the interaction of melanin with radiolytic products, another purely chemical process which may contribute to the overall level of cellular radioresistance was reported [48]. It has the nature of nonenzymatic binding of molecular oxygen by all types of natural and synthetic melanins, and not of physical sorption by these polymers, as can be deduced from the temperature dependence of the process. In melanoma cells, melanin is enclosed in melanosomes, and separated from the rest of the cell. Oxygen is a well-known radiosensitizer. Thus, any process which sequestrates it in the cell, and decreases its concentration in the direct neighborhood of organelles sensitive to radiation damage (mitochondria, the nucleus), should be associated with an enhancement of radioresistance.

There are three main mechanisms of radioprotection of cells by melanin:

1. Melanin is able to absorb the radiation itself (e.g., the UV irradiation [49,50], ionizing radiation [51,52]) due to the broadened spectrum of absorption and efficient internal conversion of the absorbed energy [32,34];

2. Melanin recombines with products of radio- and photolysis of water [37], and other compounds of melanotic cells [32,53]; 
3. Melanin consumes and adsorbs oxygen, and the process of melanin synthesis consumes significant amount of the co-substrate-oxygen (e.g., for tyrosinase [54], or phenylalanine hydroxylase [55], etc.).

As the synthesis of new melanosomes is continuous in pigmented cells $[8,19]$ this makes the stationary intracellular oxygen levels low, thus rendering the whole cell less vulnerable to irradiation (as oxygen is an efficient radio- and photosensitizer [56]).

Despite the many mechanisms of protection, the potential toxicity of melanin may in some cases outweigh the benefits of its presence in the cell as a radioprotector [57]. For example, melanin toxicity is synergic with manganese (II) ions and facilitates DNA damage in neurons [58]. Recently, it has been shown that the high-symmetry manganous complexes are responsible for radioresistance in many organisms, while complexes of low symmetry may radiosensitize the cells [59]. As the latter are created in active centers of enzymes (such as superoxide dismutases), radiation resistance may not depend on the genetically encoded ability to minimize oxidative stress, but on the actual nutritional status of the cell [59]. This may, to some extent, explain the synergistic effect of melanin and manganese (II) in cell radiosensitization, because melanin has been convincingly proven to sequestrate $\mathrm{Mn}^{2+}$ cations by means of creating low-symmetry complexes [40].

\section{Hamster as a Model of Spontaneously Occurring Melanoma}

The full history of the discovery, description, and domestication of the Syrian golden hamster (Mesocricetus auratus Waterhouse 1839) for laboratory purposes, and as pets, is exciting and worth a separate paper (supplemented with the newest discoveries, [60]). Caught near Aleppo, Syria, in 1930 [60], the golden hamsters turned out to be perfect laboratory rodents for two main reasons: easy and instant taming of the wild animals, and their extreme resistance to inbred despite a high genetic drift and founder effect [60]. As a result, the laboratory population reveals low polymorphism in the histocompatibility loci $[9,61,62]$. Consequently, the animals are able to maintain allogenic transplants, and in particular the ones of tumor tissues, in a higher percentage of cases than the wild population. Another consequence is a particular susceptibility of laboratory hamsters to human viral infections [61]. The spectrum of application of those animals as laboratory models of human diseases is thus unexpectedly wide. Helen Valentine et al. [63] described at least 17 types of human pathologies, including chronic obstructive pulmonary disease (COPD), atherosclerosis, diabetes mellitus, or amyloidosis, which have been studied using the Syrian hamster model. Hamsters are also used to study the Ebola virus [64]. It is worth reminding that the primary reason for accepting the golden hamster as a laboratory animal was its particularly high sensitivity to infections with Salmonella typhimurium, which raised researchers hope of developing a vaccine [65]. Of note, even though the works are on hold now, as the microbe is now explored as part of an alternative strategy in cancer treatment [66]. Another important feature of the Syrian hamsters is the variability in hair-coat coloration phenotypes, with numerous color mutants [67], which makes them particularly interesting objects of genetic studies and studies on the influence of hair color phenotypes on melanoma development [68].

As models for human melanoma, the Syrian hamsters turned out to develop spontaneous and chemically-induced melanomas easily, and with particular metastatic potential, especially in the first group [69]. The animals treated with carcinogens were found to develop both nests of extrafollicular melanocytes around selected pilo-sebaceous units [70] and benign pigmented nevi adjacent to the basement membrane of the epithelium [69]. They also revealed amelanotic melanocytes at the dermo-epidermal junction of the skin [71]. All of these atypical groups of melanocytes, as well as dermal melanocytes might be able to transform into melanomas $[69,70,72,73]$. Therefore, the actual origin of various types of tumors is not yet fully understood. Interestingly, the hamsters are resistant to UV-induced melanomagenesis [69,74]. Several in vivo and in vitro models of melanoma in golden hamster have been developed. The most important spontaneous melanomas are Greene melanoma models [75] (used e.g. as xenotransplants to the anterior chamber of the rabbit eye to 
study the effectiveness of hyperthermia [76] and photodynamic therapy [77]), Fortner's hamster melanoma [71,78] (known to present as ascites in the peritoneal cavity [79,80]), and Bomirski melanoma [3], described in details in the next chapters.

\subsection{Bomirski Hamster Melanoma}

The Bomirski hamster melanoma (BHM) model consists of two basic melanoma lines: melanotic $\mathrm{Ma}$ (black) and amelanotic $\mathrm{Ab}$ (white), with the latter being an example of tumor progression $[5,6,81,82]$. The original melanotic Ma line was derived from a spontaneous melanoma of the skin (located near the nose) that had appeared in a male Syrian (golden) hamster in 1959, and which has been maintained by serial transplantation among random-bred animals. The amelanotic melanoma line $(\mathrm{Ab})$ originated in 1963 from the Ma form by spontaneous alteration, which included loss of the ability to produce melanin pigment, marked increase in growth rate, loss of the ability to metastasize and decrease of the survival time $[4,5]$. Once established, these melanomas possessed a considerable degree of phenotypic stability over decades of passaging [4,5]. The two lines have been successfully transferred allogenically in hamsters for over fifty years. As a result of the faster growth of the Ab line, its transplantation interval is shorter than that of the native Ma line, although with years of passaging it has been decreasing for both lines [5], as further documented by a shorter transplantation and latency period and decrease of minimal tumor cells required for transplantability $[6,83,84]$. The subcutaneous growth of tumors is compared in Figure 2a.

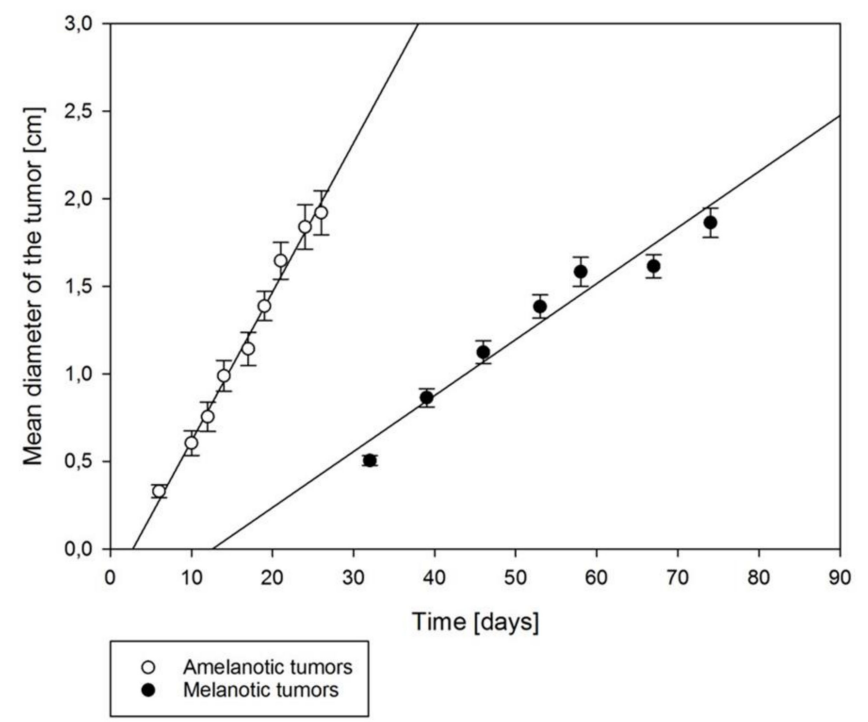

(a)

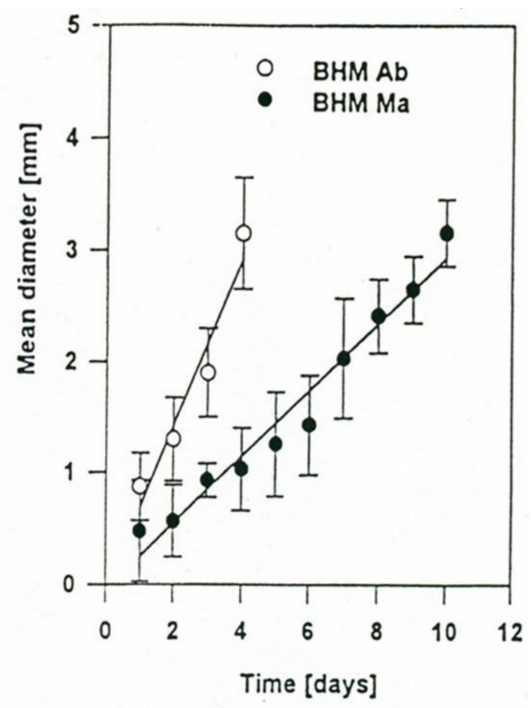

(b)

Figure 2. (a) The kinetics of Bomirski hamster melanoma (BHM) Ab and Ma tumors growth after subcutaneous implantation in Syrian Hamsters. White dots indicate amelanotic tumors growth in time, whereas black dots indicate melanotic tumors growth in time. Amelanotic tumors begin to grow 3 days after implantation, whereas melanotic tumors start growing 12 days after implantation. (b) The growth

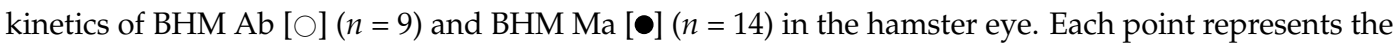
mean \pm SEM [84].

Metastases of the Ma line to lungs and regional lymph nodes have been observed from the beginning, while the $\mathrm{Ab}$ line formed metastases in kidneys and liver only twelve years after the first transplantation [5].

The $\mathrm{Ab}$ amelanotic melanoma lost the ability to synthesize melanin as a result of a block in melanosomes biogenesis, but has retained the tyrosinase activity, although at a markedly lower level than that in the Ma line [4-6]. The detectable tyrosinase activity is unique among animal amelanotic melanomas making the $\mathrm{Ab}$ line similar to human amelanotic forms expressing tyrosinase 
activity. The loss of melanin synthesis was accompanied by changes in many biological features, including a faster tumor growth rate, shorter animal survival, and changes in the ultrastructure of cells. The loss of ability to produce melanin pigment was reversible, since the cells started to produce melanin de novo when incubated in media high in tyrosine or other melanin precursors [85-90], with complex phenotypic changes dependent on the type and concentration of the melanin precursors used $[81,82,87,91-102]$.

The histological and ultrastructure analysis showed that $\mathrm{Ab}$ melanoma cells, besides the absence of premelanosomes, have an extensive Golgi apparatus, abundant ribosomes, and their plasma membrane structure and content of DNA is changed in comparison to Ma melanoma (see details in Table 1). In addition, Ma and Ab differentially influence the immunological system through modified antigenicity, immunogenicity, and cytokine secretion (details in Table 1).

Apart from the higher proportion of cells in S/G2/M phases (Table 1), the Ab line also has a decreased ability to undergo spontaneous apoptosis in comparison to the Ma line [103,104]. However, the Ab line is very sensitive to camptothecin-induced death $[103,104]$ and showed significantly higher radiosensitivity in comparison to melanotic Ma melanoma [105].

Basic metabolic parameters indicate that the $\mathrm{Ab}$ line is different in terms of the type of energy-yielding metabolism, including glycolysis and mitochondrial oxidation, and other metabolic parameters, including the pentose phosphate pathway, from the native melanotic melanoma line $[84,92,105-108]$. The native melanotic Ma melanoma cells have higher oxygen consumption than the amelanotic Ab line [106], while amelanotic melanoma has a higher rate of aerobic and anaerobic glycolysis [84], and higher basal mitochondrial transmembrane potential $\Delta \Psi$ in comparison to Ma line cells [109] (details in Table $1[6,84,106,107])$. These metabolic differences, defined by the presence or absence of melanin pigmentation, were further mechanistically substantiated by analyzing them during induction or stimulation of melanogenesis in cell culture or in isolated cells $[84,92,108]$.

Since the establishment of the BHM lines, each BHM melanoma line has maintained phenotypical stability (melanin production, growth rate, morphology) for over fifty years of transplantation. The comparative biological characteristics of melanotic Ma and amelanotic Ab BHM are presented in Table 1.

Table 1. Pathobiological parameters transplantable melanotic $(\mathrm{Ma})$ and amelanotic $(\mathrm{Ab})$ lines of Bomirski hamster melanoma model.

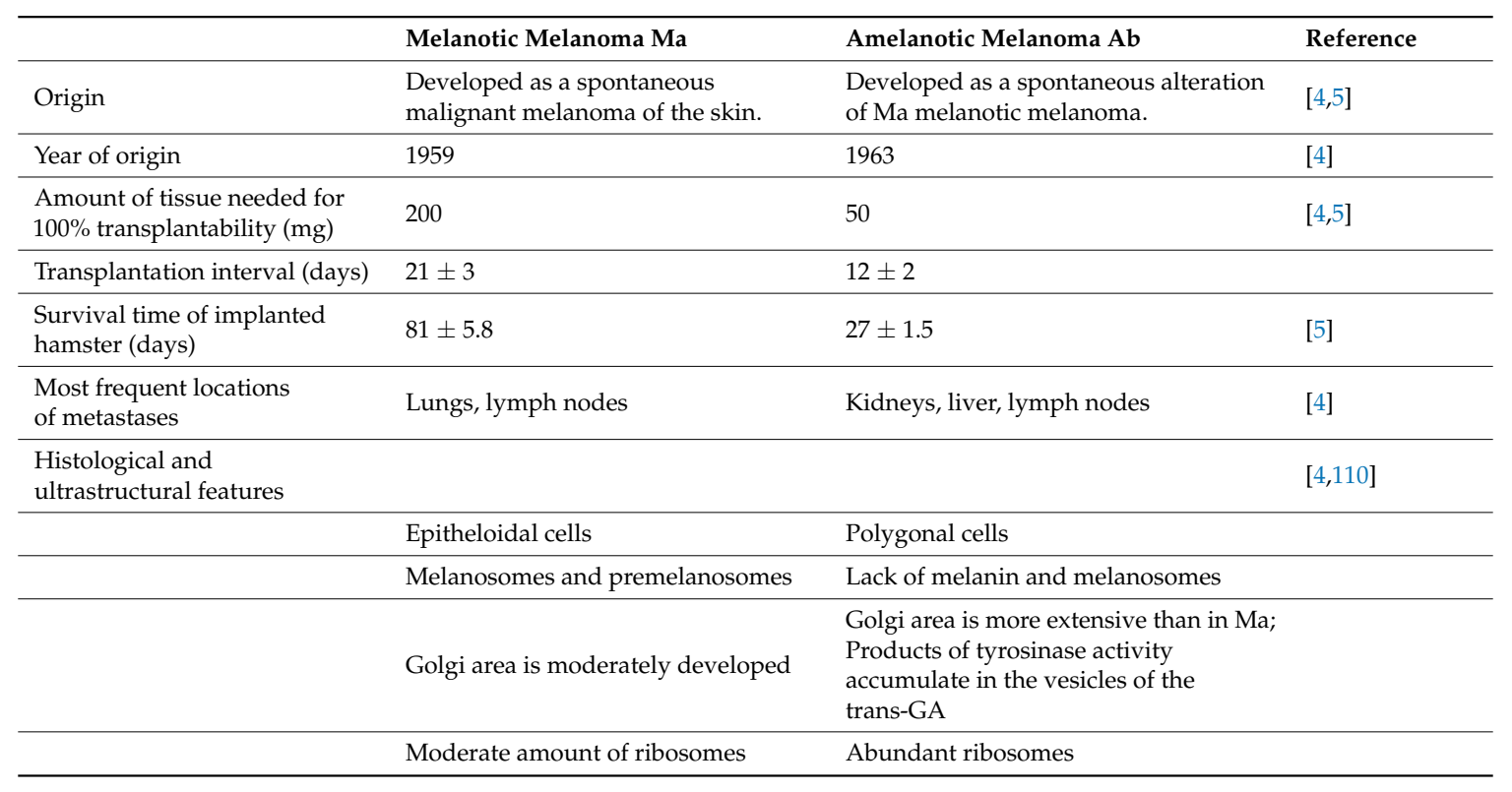


Table 1. Cont.

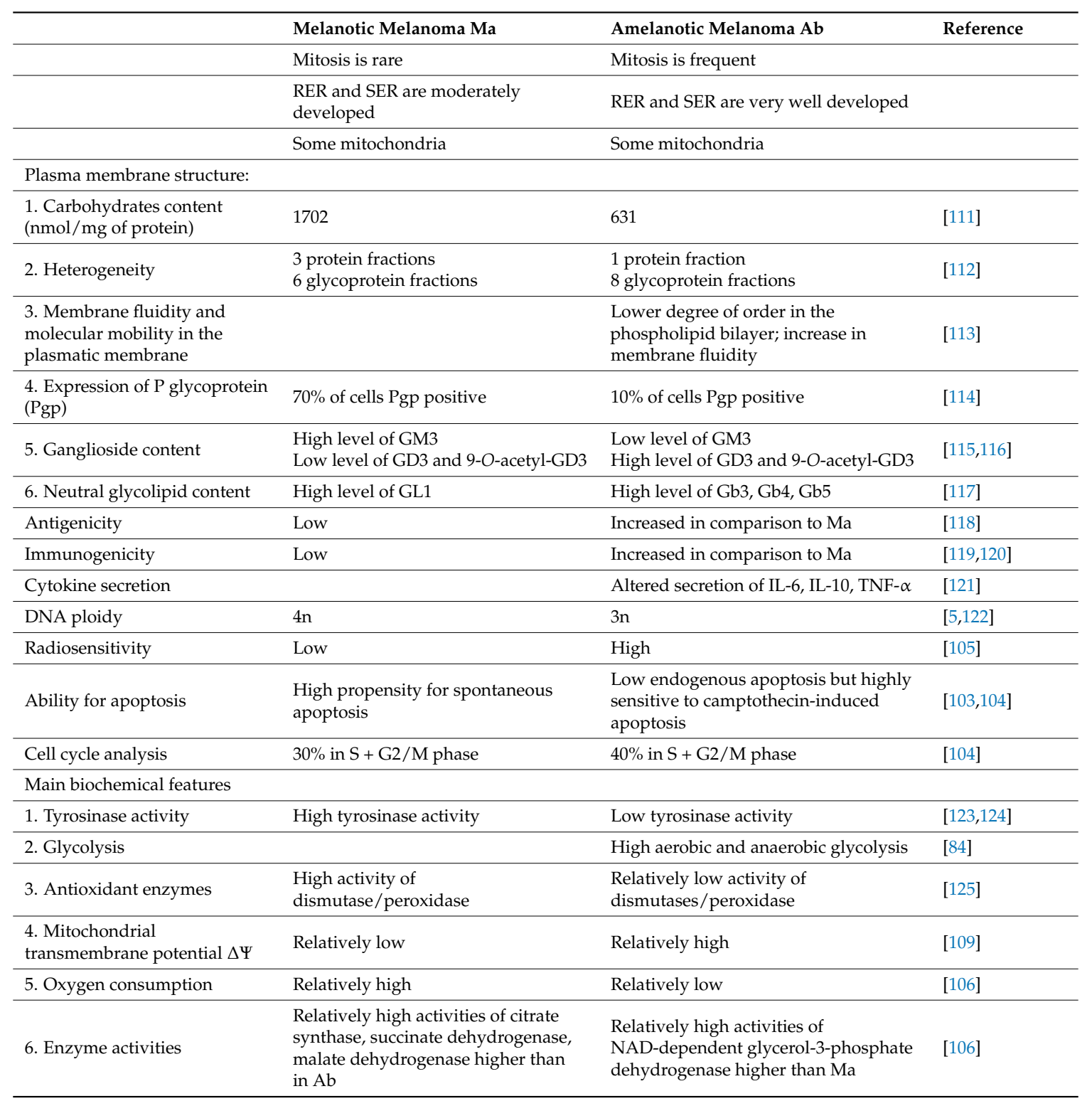

\subsection{Melanoma and Ab-455}

A third variant of transplantable Bomirski melanoma was established in 1976 from a partially depigmented passage 104 of Ma melanoma, and then transplanted subcutaneously in hamsters $[6,126]$. It differed from the parental Ma melanoma in its higher tyrosinase activity, lower pigmentation level, ability to produce pheomelanin, and slightly slower growth rate, with other parameters similar to the Ma melanoma [126]. Selection for more pigmented tissue during transplantation of MI melanoma generated another variant that differed from the MI melanoma only in terms of its higher pigmentation level [127]. Additional line Ab-455, transplantable in hamsters, was derived from the in vitro cell line originating from the primary culture of $\mathrm{Ab}$ melanoma [88]. That amelanotic tumor was tyrosinase negative, grew significantly slower than the parental Ab melanoma, and had a different metastasis pattern that was similar to the Ma melanoma. Interestingly, during serial transplantation, a rapid acceleration of Ab-455 growth occurred, rendering it similar to the original Ab melanoma [88]. 


\subsection{Radiosensitivity of BHM Growing in the Skin}

\subsubsection{Effects of Low-LET Radiation}

A striking difference between the radiosensitivity of the pigmented (BHM Ma) and nonpigmented Bomirski hamster melanoma (BHM Ab) was observed in the early 70's (unpublished). Subcutaneously growing tumors were irradiated with $48 \mathrm{~Gy}$ of fractionated X-rays (two times $7 \mathrm{~Gy}$ and two times $5 \mathrm{~Gy}$ every $24 \mathrm{~h}$, then repeated after 6 days, $50 \mathrm{kV}, 25 \mathrm{~mA}, \mathrm{Al} 1 \mathrm{~mm}, 4.98 \mathrm{~Gy} / \mathrm{min})$. The growth of both BHM $\mathrm{Ma}$ and BHM Ab tumors was inhibited, but amelanotic tumors disappeared markedly faster [128].

The higher radioresistance of pigmented cells was verified later in a more elaborate experiment involving irradiating melanoma cells in vitro, and determining the survival fraction in vivo. That step was designed in order to check if the higher radioresistance of pigmented lines originated at the tissue or at the cellular level.

Cells were irradiated in vitro, and immediately after implanted subcutaneously into hamsters, always using the same number, $10^{6}$ cells. The average rate of tumor growth was determined for each dose. The survival fraction of irradiated cells was calculated from a set of tumor growth curves, where the tumor was initiated with various cell numbers. Figure 3 shows that pigmented cells were 2.4 times more radioresistant than unpigmented BHM Ab. The mean lethal dose was 4.8 Gy for BHM Ma and 2.0 for BHM Ab [129].
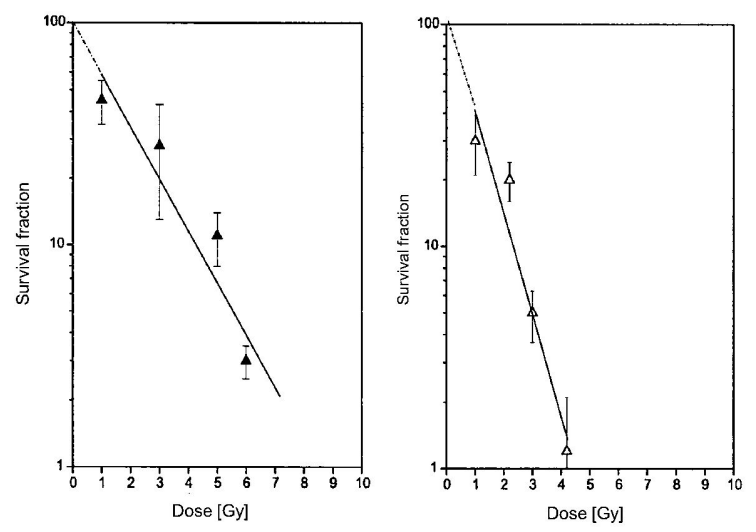

Figure 3. Pigmented cells were more resistant to X-rays than unpigmented Ab cells. The cells were irradiated in vitro, and immediately after implanted subcutaneously into hamsters, always using the same number of cells $\left(10^{6}\right)$. The average rate of tumor growth was determined for each dose, and the survival fraction of irradiated cells was calculated from a set of tumor growth curves, where the tumor was initiated with various cell numbers [129]. Copyright 1984 Gurbiel, R.

\subsubsection{Radio-Chelation Therapy}

Radio-chelation therapy is based on the combination of radiotherapy with a parallel use of chelating drugs as radiosensitizers. The latter may exert no oncostatic effect by themselves. The chelator Edathamil calcium-disodium (ECD) was combined with 20 Gy of X-rays, delivered as 4 Gy every 5 days. The highest concentration of the chelator in the tumor tissue could be achieved upon topical application of a 10\% ointment of ECD over subcutaneously (s.c.) implanted hamster melanoma. Tumor growth was inhibited for 33 days and tumor volume at day 33 was three times smaller than the control, i.e., vehicle plus radiation (Lukiewicz et al., data not published).

\subsubsection{Effects of Neutrons}

The next step was to check the radiosensitivity in the same in vitro-in vivo model against high-LET radiation, i.e., neutrons. As there is no oxygen effect in high-LET radiation, both sub-lines were expected to exhibit the same radiosensitivity. Indeed, experiments demonstrated that the then striking 
difference in radiosensitivity between $\mathrm{Ma}$ and $\mathrm{Ab}$ lines, clearly visible for low-LET radiation (X-rays), disappeared for the irradiation of the two tested sub-lines with 5.5 MeW neutrons (Figure 4).
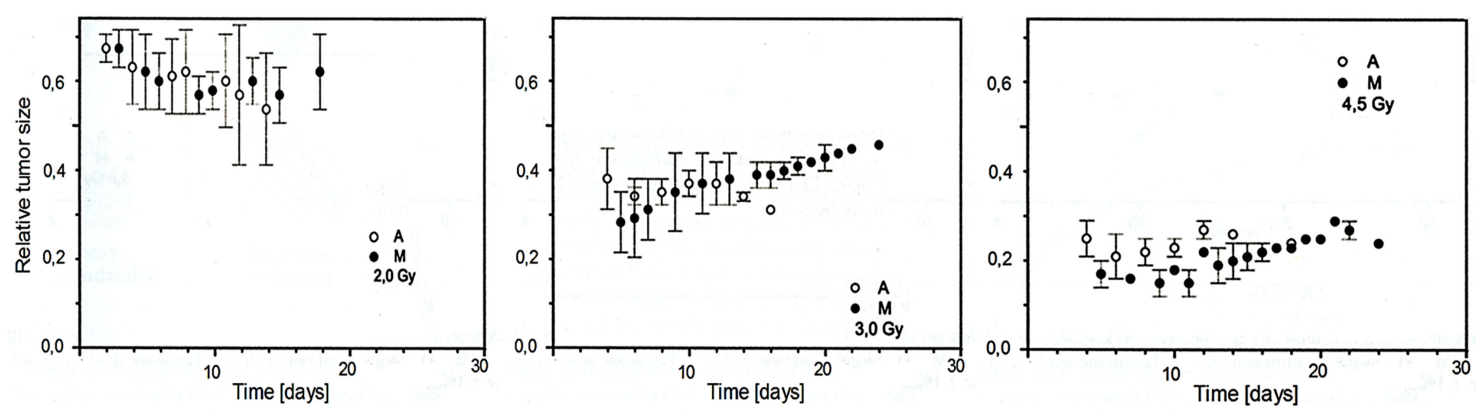

Figure 4. No difference in radiosensitivity between $\mathrm{Ab}$ and Ma cells treated with neutrons [130]. Copyright 2000 Urbanska, K.

\subsection{Radiosensitivity of BHM Tumors Transplanted in the Eye}

Several animal models of ocular melanoma were proposed, including implantation of skin melanoma into the eye, such as the Greene melanoma, B16 [131], or human uveal melanoma in the nude mouse eye $[117,132-135]$. Hu successfully established mouse xenografts in the choroid of an immunosuppressed rabbit using B16F10 cell line [134]. Our ocular tumor model of melanoma was obtained by implanting small pieces of BHM, freshly excised from the cutaneous tissue, into the eye of the Syrian hamster (Mesocricetus auratus) [135]. Tumor fragments sized 0.4-1.0 mm were implanted into the anterior chamber (AC) of the eye. During the first 2 to 3 days, disappearance of the implants was observed, followed by the appearance of iris tumors after 4-6 days in the case of BHM Ab, and after 8-10 days in the case of BHM Ma. When the AC was completely filled with the tumor mass, the eye was enucleated, and the animals were observed for metastases, developing within 20-30 days in the lung. Melanoma cells growing in the iris in the form of nodules infiltrated all surrounding tissues, and the ciliary body in particular, and always remained pigmented. The distant metastases, assessed macroscopically, were encountered in the lungs (after 48 days in $100 \%$ of animals), and sometimes in the kidneys (after 48 days only sporadically) as well as in the regional lymph nodes which were also clearly enlarged $[5,136]$.

The vasculature of BHM tumors growing in the eye was mainly induced from the anterior capillary and antero-venular layers of the iris. As it was revealed by scanning electron microscopy of vascular corrosion casts (Figure 5), the tumor vasculature was characterized by pronounced tortuous courses of the blood vessels with uneven contours and variable diameters. All vessels were highly irregular and heterogeneous, with many embolizations, fenestrations, and sprouting. Venules and sinusoidal capillaries, exhibiting heterogeneous intra-tumor density, were intensively interconnected. Avascular areas were also seen. The presence of numerous nodular outgrowths, varying in size, on he surface of dilated venules and venous vessels represents morphological evidence for the continuous remodeling of tumor vasculature. The observed features of the vascular system seem to provide a pathway for further tumor expansion [137].

Although BHM is a cutaneous melanoma, the development of spontaneous metastases is an advantage of the model [136]. Also, unlike the rabbit model, BHM melanoma is allotransplanted with hamsters being both the donor and the recipient of the graft. This eliminates immunological complications such as graft rejection, which can occur after the transplantation of hamster melanoma (Greene melanoma) into the rabbit eye. 

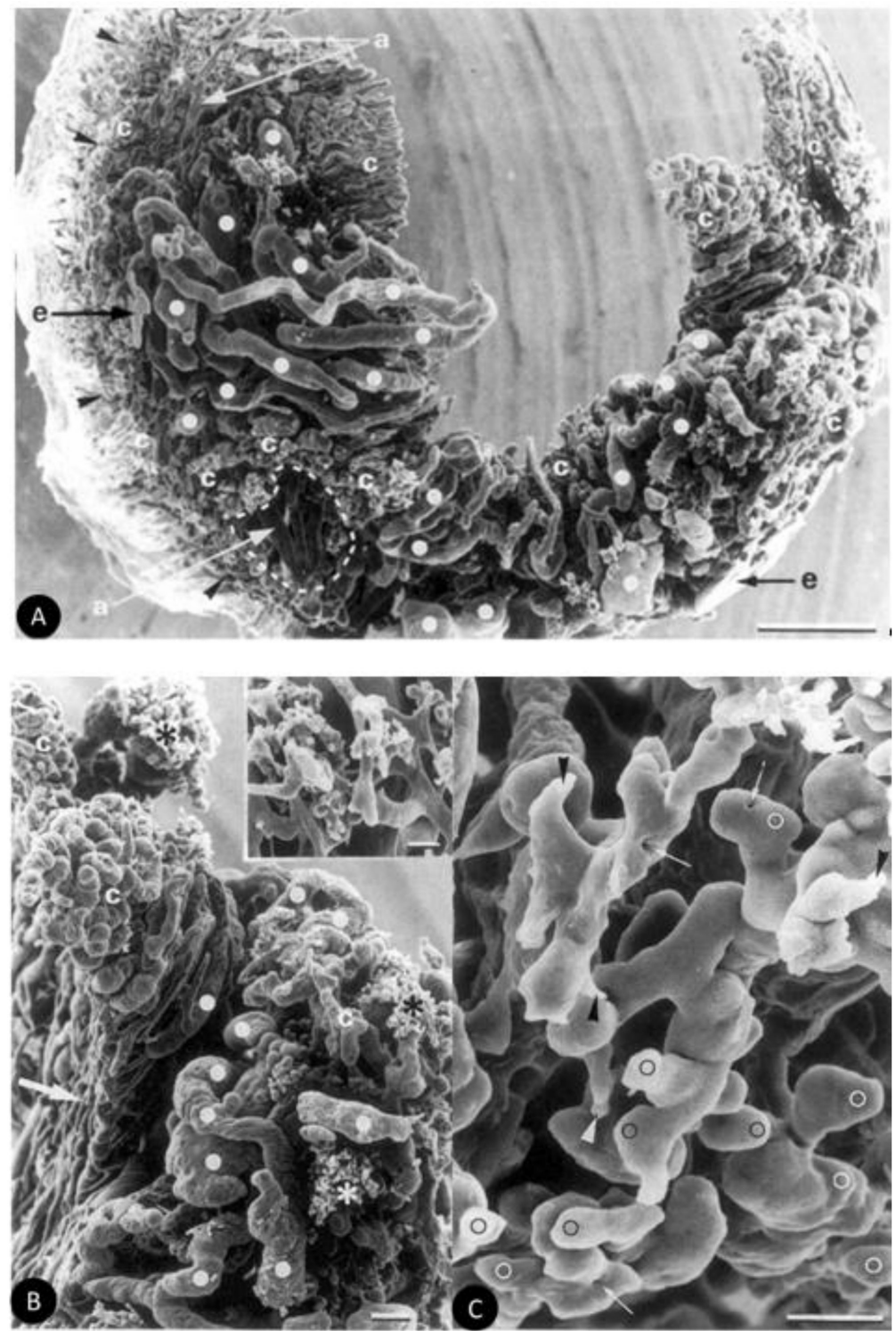

Figure 5. (A) Tumor vasculature cast revealing a missing vessel hierarchy and heterogenous vascular density. Strongly dilated venous vessels (full white circles) and capillaries (c) predominate over few arterial feeders (a) Nodular, nest-like, avascular areas, surrounded by tufts of capillaries with short terminal branches, are marked with a dashed line. The external perimeter of tumor vasculature is indicated with arrowheads. Extravasation of resin is also visible (e) Bar $=500 \mu \mathrm{m}$. (B) Fragment of intratumor vasculature showing strongly dilated venous vessels (full white circles) interconnected with loops formed by wide sinusoidal capillaries (c) Tufts of capillaries with short terminal branches are indicated (asterisks) and shown in higher magnification (inset). Note also the posterior vascular layer of the iris (arrow). Bar $=100 \mathrm{gm}$ and $50 \mathrm{gm}$, respectively. (C) Vascular sprouts (arrowheads) and globular outgrowths (white circles) on the proliferating, dilated tumor capillaries. Note also the tiny holes (arrows) typical of the intussusceptive angiogenesis. Bar $=500 \mu \mathrm{m}$. Reproduced with permission from Annals of Anatomy [137]. Copyright 2001 Elas, M.

\subsubsection{Effects of Low-LET Radiation}

Since 2000, the hamster model of melanoma located in the eye has been applied to study distant metastases studies [130]. Two sub-lines differing in their melanin content were compared with regard to their radiosensitivity to ruthenium-106 $\left({ }^{106} \mathrm{Ru}\right)$ radiation. Tumors growing in the iris were treated with 3, 6, or $10 \mathrm{~Gy}$ of ${ }^{106} \mathrm{Ru}$ administered as a single dose or in four fractions at $24 \mathrm{~h}$ intervals. 
Dose-dependent delay of tumor growth was observed in both melanomas. Following the treatment with a dose of $6 \mathrm{~Gy}$, the amelanotic (BHM $\mathrm{Ab}$ ) tumors grew 2.6 times slower, and the melanotic (BHM Ma) tumors 1.4 times slower than the untreated ones. Exposure to $\beta$-radiation from ${ }^{106} \mathrm{Ru}$ did not significantly affect either the number or the size of metastases, except at a dose of $10 \mathrm{~Gy}$, where a statistically significant decrease in the number of metastases was found in the melanotic sub-line (BHM Ma) [138]. Histological analysis showed signs of tumor blood vessel damage such as endothelial cell swelling, erythrocyte extravasation, and tumor necrosis. These signs increased with the rising dose of $\beta$-radiation. Change of fractionation from four equal doses to a boost dose of $4 \mathrm{~Gy}$, followed by $3 \times 2$ Gy, caused a complete inhibition of metastases for 70 days (unpublished data).

\subsubsection{Radiotherapy Using Proton Beam Irradiation}

A single dose of $10 \mathrm{~Gy}$ of proton beam irradiation delayed the growth of BHM Ma melanoma in the hamster eye by 10 days [138]. Albeit the inhibition of the implanted tumor growth was moderate, proton therapy noticeably reduced the mass of the metastases in the lung in comparison with untreated tumors (Figure 6). On average, $10 \mathrm{~Gy}$ of proton irradiation diminished the mass of metastases 4.35 times, even though there was a significant spread between individual animals (Figure 6). These results are in agreement with data presented for osteosarcoma [139]. Likewise, proton beam irradiation decreased cell migration and invasion in a dose-dependent manner and strongly inhibited matrix metalloproteinase 2 (MM-2) activity in highly aggressive HT 1080 human fibrosarcoma cells in vitro [139]. Similarly, it was shown that in vitro models, the adhesion, migration, invasion, and the level of expression or activity of molecules related to metastases, such as $\alpha \mathrm{V} \beta 3, \beta 1$ integrin, and MMP-2, were all decreased, even after treatment with small doses of proton beam [140].
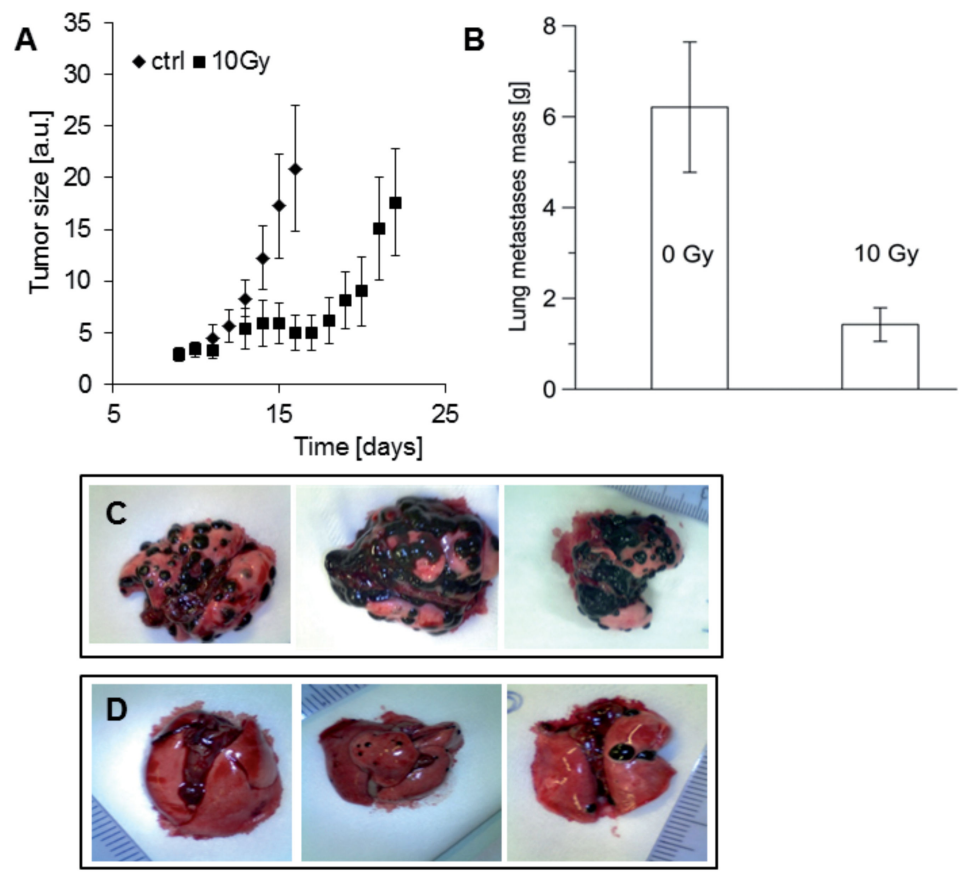

Figure 6. (A) Inhibition of BHM melanoma tumor growing in the hamster eye, irradiated with a proton beam at a single dose of $10 \mathrm{~Gy}(n=7$, black square), as compared with the untreated control $(n=6$, black diamond). (B) The mass of lung metastases decreased 4.35 times as a result of the proton beam irradiation (10 Gy) of BHM melanoma tumor growing in the hamster eye ( $p=0.0052)$. Average mass with SEM is shown. The number of control animals was six, and the number of irradiated animals was seven. Representative isolated lungs with metastases from untreated (C) and irradiated (D) animals. Reproduced with permission from [138]. 


\subsubsection{Radio-Phototherapy}

Studies on the effects of photodynamic therapy (PDT) combined with $\gamma$-radiation on the BHM transplanted into the eye were especially important as both of the methods are non-invasive and thus prevent surgical intervention. The main advantage of ionizing radiation is the deep penetration of radiation into the tissue, where it inhibits cell division. PDT, on the other hand, targets mainly tumor cells, but visible irradiation, using the preferred excitation wavelength for the MC540 sensitizer, penetrates only partly into the tumor tissue. Combining PDT with a very low-dose rate of $\gamma$-irradiation was found to lead to tumor inhibition [141]. Although the histological damage was severe for both lines, the non-pigmented BHM Ab line was more sensitive and responded better than the pigmented melanoma. The most significant inhibition was obtained when both the $\gamma$-radiation and PDT were delivered in doses spread over time. Such treatment resulted in 6 weeks of inhibition, a far greater length of time than the inhibition period observed after a single treatment ( 2 days for non-pigmented cells and 4 days for the pigmented ones).

The significant increase in effectiveness with the four divided combined treatment doses may be due to radiation-induced depletion of the viable stem cells. That finding agrees with the results obtained in the rabbit eye for Greene melanoma [94]. The cumulative results indicate that MC540-mediated PDT in combination with ionizing radiation has significant effects on the rapidly growing melanoma in the eye [142].

\section{Gerbils as Animal Models for Chemically-Induced Melanomas}

The Mongolian gerbil belongs to the family Muridae, subfamily Gerbillinae, order Rodentia [143]. Gerbils are small rodents that occur naturally in the desert regions of Northeast China, Eastern Mongolia and the steppes of Russia [144], living in small colonies in extended burrow systems [145]. They have several phases of twenty-four-hour activity; the two most active periods are just after dawn, and around dusk, but many gerbils remain active throughout the day [146].

Gerbils have been used for scientific purposes since the 1880s, beginning with the research on tuberculosis; they also played a significant role in bilharzia research during the 1950s-1960s [147]. Due to its characteristic behavioral and physiological features, gerbils were used in a wide spectrum of research, covering a variety of research fields, including behavioral investigations [148], biological and behavioral processes of aging [149], epilepsy [150], infectious diseases [151-153], dermatitis, neurology research, audiometry and sound effect, coat color genes [154], melanin and tyrosinase activity [155], and others. The gerbil is an important laboratory animal in oncology research [8,156-158].

\subsection{Zeman UJ90 Melanoma}

Gerbils have also played a special part in the history of research carried out at the Department of Biophysics of the Jagiellonian University in Krakow. In the 1990s, in the animal facility of the Department of Biophysics of the Jagiellonian University in Krakow, a melanotic tumor was found on the ear of one animal from a group of Mongolian gerbils, previously treated with $\mathrm{N}$-ethyl-N-nitrosourea. This compound has been described in the literature as a carcinogen with a particular affinity to cells of neural origin [159], showing a preference for places rich in pigment, hairy areas, and those often exposed to the sun (paws, ears, and tail). It can induce tumors in $40 \%$ of gerbils exposed to that carcinogen [160]. The tumor was transplanted into other related animals of the breeding stock, which had been maintained by inbred crossing. Thus, a new transplantable Zeman UJ90 melanoma line in gerbils was stabilized [7]. This transplantable melanoma line was used to carry out in vivo Electron Paramagnetic Resonance (EPR) experiments. In contrast to the golden Syrian hamsters, gerbils have a long tail that can be placed inside a resonant cavity, similar to mouse tails inoculated with melanoma. That observation was a good starting point for further extensive research, most of which has been published, and is briefly reported below. 
As a desert animal, the Mongolian gerbil comes from a microbiologically pure environment and reveals an impaired immunological reactivity to some immunological stimuli. It is manifested by a weak response of the animal's macrophages to latex particle challenge [161], and also by weak graft-versus-host [162] and mixed lymphocyte responses from allogenic mixed cultures [163]. Those features may additionally suggest a weak reactivity of the NK cells, and also a low histocompatibility variability, resulting from a high inbreeding level in their breeding stocks. It turned out that the animals revealed a weak response of iNOS (inducible nitric oxide synthase), manifested in EPR studies by showing a low levels of nitric oxide and their hemoglobin complexes (nitroso-hemoglobin, $\mathrm{HbNO}$ ) in tumors growing in situ. That was entirely different from other animal tumors studied by us, but similar to human tumors $[164,165]$. As solid tumors of BHM revealed the HbNO signal, its lack of expression in gerbil tumors must have been a result of low iNOS activity rather than the low polymorphism of histocompatibility genes. The EPR signal of $\mathrm{HbNO}$ in Zeman UJ90 tumors could be induced only by a strong immunological stimulus-lipopolysaccharide (LPS) [166,167]. The existence of amelanotic sub-line (see further) made it possible to demonstrate the time- and dose dependence of the $\mathrm{HbNO}$ EPR signal intensity on LPS, and its inhibition by analogs of L-Arginine, the substrate for NO synthesis by iNOS [168]. That extraordinary property of those laboratory animals could also be demonstrated by a slower and lower response of gerbils to xenotransplants of rat heart tissues, and a weaker dependence on pre-sensitization with donor splenocytes [169]. The ability to induce NO synthesis by LPS served to demonstrate an in vivo production of NO by spin-trapping at S-band, which was followed by in vivo observations of NO production in melanoma in situ. These findings were observed in animal (gerbil and mouse) tails placed inside the resonant cavity [170].

Initially, the Zeman UJ90 line was heavily pigmented and grew slowly. After the fourth passage, a rapid acceleration of growth was observed and the FGM (Fast Growing Melanoma) sub-line emerged. During the seventh passage, a part of the growing tumor was completely devoid of pigment. A second amelanotic sub-line (A-FGM) was derived from that fragment (Figure 7). In the case of the Zeman UJ90 melanoma, the non-pigmented sub-line has a greater capacity to create metastases (in $80 \%$ of the implanted animals) in comparison to the pigmented sub-line (33\% animals) [7]. The observed phenomenon stands in contrast with the case of Bomirski hamster melanoma, where a higher metastatic capacity was reported for the heavily pigmented BHM Ma line [5]. Comparison of the regression line slopes revealed that the rate of growth of the A-FGM sub-line was about three times lower than that of the melanotic M-FGM sub-line, which was consistent with the observed difference in tumor size measured after the experiment. This change towards a slower growth rate of the non-pigmented amelanotic line was also unexpected, as experimental amelanotic tumors tend to grow faster (less differentiated), being better oxygenated and nourished (better blood-supply) than melanotic ones $[6,127,171,172]$. However, this is not always the case, as shown for the hypomelanotic BMH MI, which grows slower than the more pigmented Ma melanoma [126]. Selection of BHM MI for less and more pigmented variants generated sub-lines with significantly different levels of melanin and tyrosinase, but without any significant effect on growth rate [127]. 


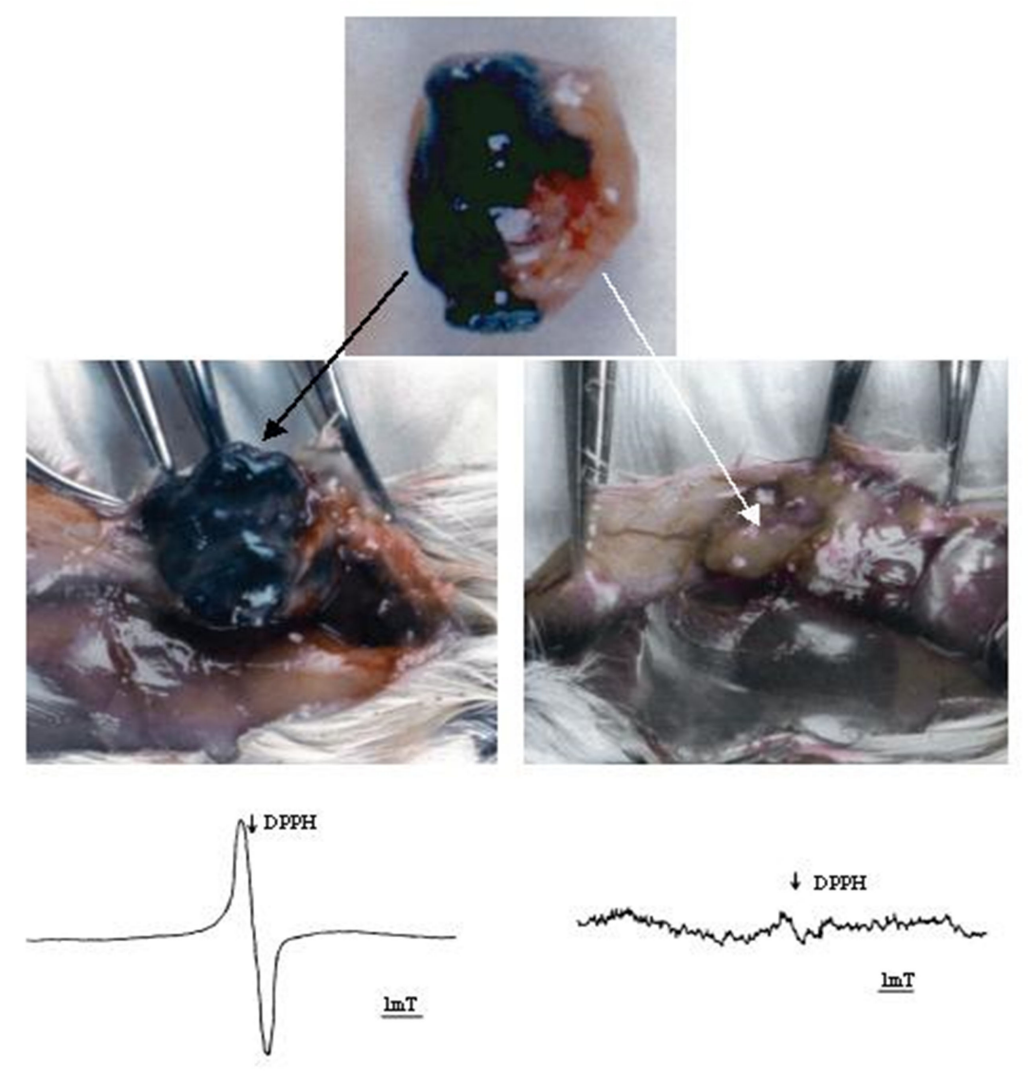

Figure 7. Electron paramagnetic resonance (EPR) analysis of melanotic (left EPR spectrum) and amelanotic tumors (right) of Zeman UJ90 melanomas, corresponding to the black and white tumors (photographs in the middle row). The white tumor was obtained from the white parts of the two-color tumor which appeared in passage 7 (upper photograph). DPPH: the position of a free radical signal $(g=2.0037)$. Reprinted with permission from Copyright 2003 John Wiley \& Sons Ltd. [8].

\subsection{Irradiation of Zeman UJ90 Melanoma}

The melanotic and amelanotic versions of Zeman UJ90 melanoma turned out to be interesting models to determine tumor sensitivity to $X$ radiation, and they were exposed to low radiation doses. The response to the doses of 5 and 10 Gy was weak, which was not surprising. Radiation has an inhibitory effect on tumor growth: both the pigmented and the non-pigmented forms grew slower after irradiation than in the control arm. The effectiveness of $X$ radiation increased linearly with the dose applied, which was expected. Unexpectedly, melanin did play a radioprotective role for the tumor, unlike in the case of hamster tumors. However, that was not a unique or isolated phenomenon [57].

The radiological phenomena associated with Zeman UJ90 melanomas are congruent with earlier observations on a general radioresistance of Mongolian gerbils [173-176]. All that makes the Mongolian gerbil a really unique laboratory animal in the context of melanoma radiotherapy studies. In this context, one can conclude that the actual radioprotection of melanin strongly depends on the model involved, and in clinical practice on the particular case in question and the stage of tumor development [57,177]. 


\section{Human Melanoma}

\subsection{Radiosensitivity of Human Skin Melanoma/Why Is Radiation Not Used in the Treatment of Human Skin Melanoma}

Prevention, early diagnosis, and surgical excision of the tumor, when the disease is localized to the skin, represent the golden standards of melanoma management $[178,179]$. Recent advances in melanoma therapy have led to a successful use of targeted therapy or therapy based on modulations of immune responses, while managing stage III-IV disease [180-182]. Although such strategies are associated with adverse effects, financial costs, and development of tumor resistance mechanisms resulting in recurrent disease and ultimate death (discussed in [82,182-186]), systemic strategies are preferred in most clinical settings.

The past reluctance to apply radiotherapy in melanoma treatment was secondary to the opinion that melanomas in general were resistant to radiation [187]. However, significant evidence has been accumulated, indicating that melanomas have a wide range of sensitivity to radiation $[187,188]$. Currently, radiotherapy is used in selected patients with lentigo maligna melanoma, and as an adjuvant or palliative approach in selected patients with regional or systemic metastatic disease [189-194]. It must be noted that some authors recommended caution in the use of adjuvant radiotherapy that should be reserved for high-risk patients, because of its negative impact on overall survival [192]. Interestingly, beneficial effects of adjuvant radiotherapy have been documented for desmoplastic, lentigo maligna, and mucosal melanomas [192-201]. The use of radiotherapy in the treatment of lentigo maligna may require some selectivity, because of the superiority of the surgical approach [202] and an attractive alternative, i.e., topical treatment with imiquimod [203]. The most promising are the effects of radiotherapy in adjuvant treatment of desmoplastic melanomas $[193,195,196,204]$ that are devoid of melanin pigment $[179,202]$.

Therefore, it can be safely concluded that radiation should be considered as an adjuvant therapy, depending on the context. Also, the presence or lack of melanin pigmentation should be considered, when selecting different therapeutic options, because melanogenesis may affect the behavior and metabolic status of melanoma cells $[15,19,92,108,205,206]$. The latter consideration is in agreement with recent clinical and pathological studies that have demonstrated that the presence of melanin in metastatic melanomas attenuated the positive outcome of radiotherapy [177].

\subsection{Radiosensitization of Melanoma Cells through Inhibition of Melanoma Pigmentation}

Experimental, cell culture-based studies showed radioresistance of melanoma cells, but the first results related to the sensitivity of human melanoma cell lines with different pigmentation levels to ionizing radiation were contradictory. While Kinnaert et al. [207] found that non-pigmented melanoma cells had a significantly lower resistance to $X$ radiation than the pigmented ones, Barranco et al. [208] observed a high radioresistance of melanoma cells, independent of their pigmentation levels, in three different melanoma cell lines. However, those discrepancies could have arisen from different genotypes of the melanoma cell lines under investigation. Our study, using one line of melanoma cells SKMel-188, with different melanogenesis dependent on the melanin precursor levels in the medium [209], eliminated the impact of genomic differences on the radiosensitivity of melanoma cells [210]. The human melanoma cell line SKMel-188 is characterized by inducible melanogenesis. Under the conditions of low levels of melanin precursors in culture medium melanoma cells remain amelanotic, whereas when cultured in the presence of high levels of melanin precursors, the cells become melanotic $[92,108,206,209,211]$. Pigmented SKMel-188 melanoma cells showed higher viability after gamma irradiation and increased melanogenic activity was positively correlated with melanoma cell viability after irradiation with $15 \mathrm{~Gy}$ gamma radiation $(r=0.8, p<0.0001)$. Tyrosinase activity inhibition with N-phenylthiourea or copper-chelating agent, D-penicillamine, resulted in an increased sensitivity to gamma radiation, and decreased survival after irradiation [210]. Interestingly, the same approach might potentially sensitize melanoma cells to chemo- or immunotherapy [15,82,206,212]. 
Our recent clinical-based study showed that melanogenesis in human cutaneous primary metastasizing melanomas (stages III and IV), and in lymph node melanoma metastases, was related to a shorter overall and disease-free survival [16]. A subsequent analysis revealed that melanoma patients with amelanotic metastatic tumors showed significantly longer survival after radiotherapy, and longer overall survival time than patients with pigmented tumors, who received either radiotherapy or chemotherapy and radiotherapy [177]. Additionally, Shields and co-authors observed that the presence of melanin was found to be an unfavorable marker of metastasis and death in a multivariable analysis of ciliary body and choroidal melanomas [213,214].

Thus, the experimental and clinical data indicate that inhibition of melanogenesis could be used for the radiosensitization of melanoma cells to ionizing radiation to improve melanoma radiotherapy efficacy.

\subsection{Radiosensitivity of Uveal Melanoma Tumors}

\subsubsection{Brachytherapy in Clinical Practice}

Human melanomas are less radiosensitive as compared with some other neoplasms due to a slower cell turnover, but most of the uveal melanomas (UM) show satisfactory regression after radiotherapy. Radiotherapy of intraocular melanoma is a therapeutic method used next to surgery. Both external beam and brachytherapy (plaques) are used. Plaque brachytherapy (ruthenium or iodine) is the most common conservative treatment in the management of choroidal melanomas, followed by proton beam radiotherapy. Brachytherapy has been used to treat intraocular tumors since 1930. Consecutive publications report ${ }^{60} \mathrm{Co},{ }^{106} \mathrm{Ru},{ }^{125} \mathrm{I},{ }^{103} \mathrm{Pd},{ }^{90} \mathrm{Sr}$, and ${ }^{130} \mathrm{Cs}$ sources [215]. The most commonly used are $\mathrm{Ru}$ (beta emitter, recommended for small and medium-sized tumors) and I plaques (gamma irradiation with deeper penetration). The prescription dose range is 70-100 Gy [216]. The COMS (Collaborative Ocular Melanoma Study) study compared enucleation to ${ }^{125} \mathrm{I}$ brachytherapy in medium-size tumors. There was no difference in melanoma-associated and overall-cause mortality between the two treatment modalities. The COMS study was restricted to the use of ${ }^{125}$ I plaques [217]. The five-year local control rates after brachytherapy averaged at $89.5 \%$ (range $69.9-97.9 \%$ ). The recurrence rate following ${ }^{106} \mathrm{Ru}$ brachytherapy was $3-16 \%$ in various studies [217]. However, brachytherapy also affects the intraocular structures, sclera, ocular muscles, conjunctiva, corneal surface integrity, tear production, eyelashes, and eyelids. Within the eye, radiation can cause cataract, retinopathy, optic neuropathy, hemorrhage, retinal detachment, neovascularization, and secondary glaucoma. The side effects involved may result in severe deterioration or the loss of vision. Results of various studies [218] using different analytical techniques and visual acuity endpoints, have indicated that visual acuity is generally preserved in patients with smaller uveal melanoma situated farther from the optic disc and fovea. At 10 years' follow-up, $68 \%$ of patients demonstrated poor visual acuity [218].

\subsubsection{Proton Beam Radiotherapy (PBRT) of Uveal Melanoma}

Teleradiotherapy is the second method of radiotherapy, next to brachytherapy, dedicated to uveal melanoma patients. PBRT has been the most commonly used option amongst all types of teleradiotherapy, since the 1970s. Charged particle therapy of uveal melanoma is successfully applied in many clinical centers around the world. PBRT is characterized by a very precise dispersion of radiation that enables destruction of the targeted neoplastic tissue at various depths in the body.

Proton beam radiotherapy is particularly dedicated to lesions located close to the optic disc and macula [216-222]. In intraocular neoplasms, proton beam radiotherapy has the same effect on the survival rate as brachytherapy [216-222].

Verma et al. summarized fourteen original investigations from 10 different institutions, conducted from 2000 to 2015. In that analysis, five-year local control rates exceeded $90 \%$, which persisted at 10 and 15 years. Five-year overall survival rates ranged from $70 \%$ to $85 \%$, five-year metastasis-free survival 
and disease-specific survival ranged from $75 \%$ to $90 \%$, with a more recent series reporting higher values. With the removal of smaller studies, five-year enucleation rates were consistently between $7 \%$ and $10 \%$. Many patients (60-70\%) showed a post-PBRT visual acuity decrease, but still retained purposeful vision $(>20 / 200)$ [223].

The above results are comparable with our outcomes. We observed a 93.3\% local control rate, and deterioration of visual acuity in $60 \%$ of patients. Complications were observed in $31.5 \%$ of cases (dry eye syndrome, glaucoma, cataract, retinopathy, maculopathy, and neuropathy). Enucleation was performed in $2.8 \%$ of the cases, due to a massive melanoma relapse or neovascular glaucoma with a massive vitreous hemorrhage [221,224].

Proton beam radiotherapy enables a very high local tumor control, and preservation of the eyeball in many cases, with visual acuity depending on the tumor size and location.

\subsubsection{Proteomic Study of Human Skin Melanoma Cells (BLM) Treated with Proton Beam Irradiation}

Proteomic analysis of the BLM melanoma cell line irradiated with a low dose of 3 Gy of proton beam shows a significant (more than $1.5 \times$ change) upregulation of 13 proteins and downregulation of four proteins [225]. These proteins might be roughly grouped into four categories by their function: (i) DNA repair and RNA regulation (VCP, MVP, STRAP, FAB-2, Lamine A/C GAPDH); (ii) cell survival and stress response (STRAP, MCM7, Annexin 7, MVP, Caprin-1, PDCD6, VCP, HSP 70); (iii) cell metabolism (TIM, GAPDH, VCP); and (iv) cytoskeleton and motility (Moesin, Actinin 4, FAB-2, Vimentin, Annexin 7, Lamine A/C, Lamine B). Of particular interest is the substantial decrease $(2.3 \times)$ in vimentin, a marker of EMT and of the metastatic properties of melanoma [226]. Future works will include other cancer lines, such as uveal melanoma or prostate cancer, both of which respond well to proton beam therapy.

\subsubsection{Radio-Phototherapy of Uveal Melanoma}

Indocyanine green (ICG) photodynamic therapy administered with brachytherapy was tested in a clinical setting, involving 38 patients [227]. The baseline ICG study showed pathological intrinsic vasculature in all examined cases. Six months after the indocyanine-PDT treatment, changes in microcirculation were detected in all cases as well as a significant decrease in tumor thickness in ultrasonography (mean 38\%). A complete regression of intrinsic vessels was demonstrated by indocyanine green angiography in 26 cases, and partial regression of pathological vascularization was found in 12 patients. In the Campagnoli study, involving five patients with amelanotic choroidal melanoma treated with PDT, four patients did not respond to treatment [228]. They concluded that radiotherapy was the main damaging agent, with phototherapy effects considered negligible. Contrary to the above, verteporfin-PDT as primary treatment in small choroidal melanomas resulted in an $80 \%$ rate of local tumor control [229], which slightly lower than in classical brachytherapy.

PDT treatment of skin melanoma was reviewed and its efficacy was dependent on the photosensitizer used, and moderate effects were seen when PDT was used in combination with immunotherapy, but not with radiation [230].

\subsubsection{Radio-Chelation Therapy in Clinical Trials}

Cuprenil and Chelaton (Polfa) were used as radiosensitizers in patients treated with ${ }^{60} \mathrm{Co}$ gamma rays (brachytherapy) for choroidal melanoma in a pilot study. Chelators were administered for 7-10 days before, and 9-14 days during the brachytherapy. Tumor size was determined 8 weeks and 16 weeks after treatment. Tumor size volume decreased approximately $45 \%$ at 16 weeks after Cuprenil treatment. The sensitizing action of chelators may be due to the inhibition of oxygen consumption in melanotic cells by those compounds [231], and inhibition of melanogenesis as shown in other models [206,210]. 


\section{Conclusions}

Since malignant melanomas are responsible for the highest mortality rate among patients with skin cancers, and exhibit a high incidence rate in the white population, it is of utmost importance to develop and test multiple therapeutic strategies, using appropriate animal models. This is crucial for advanced melanomas at the vertical growth phase or metastatic disease. An impressive progress has been made in the development of new strategies in targeted therapy and immunotherapy and other treatment modalities. However, there is a lack of optimism, with respect to long-term survival of melanoma patients, because of the pre-existing or acquired resistance developing to the applied therapies.

Radiotherapy is used in the intraocular melanomas with satisfactory outcomes. Both external beam and brachytherapy are utilized in the treatment of uveal melanomas. For brachytherapy, ${ }^{60} \mathrm{Co}$, ${ }^{106} \mathrm{Ru},{ }^{125} \mathrm{I},{ }^{103} \mathrm{Pd},{ }^{90} \mathrm{Sr}$, and ${ }^{130} \mathrm{C}$ are the available radiation sources, with the most commonly used beta emitter being ${ }^{106} \mathrm{Ru}$, and gamma irradiation $\left({ }^{125} \mathrm{I}\right)$ preferred for tumors with deeper penetration. Proton beam radiotherapy constitutes the second method of radiotherapy that enables efficient local tumor control with relative preservation of the eyeball, depending on disease progression. Radiotherapy is rarely used in cutaneous melanomas, except for a palliative approach in selected patients, likely due to the long-held opinion that melanomas are resistant to radiation. The resistance may in part be explained by the radioprotective properties of melanin. Interestingly, desmoplastic melanomas, which are amelanotic, are responsive to radiotherapy. Therefore, radiotherapy represents a viable alternative in the treatment of melanomas, depending on the tumor phenotype and location.

The discussed models of rodent melanoma, namely the Bomirski and Zeman melanoma lines transplantable in hamsters and gerbils, respectively, constitute remarkable animal models to study and test different radiotherapeutic approaches before clinical treatment of stage 3 and 4 disease. Specifically, non-pigmented BHM melanoma is responsive to radiotherapy, either after subcutaneous transplantation or implantation into the eye. Similarly, Zeman melanoma is radiosensitive, but independently on pigmentation, while pigmented BHM melanomas are markedly more resistant to $X$ irradiation than non-pigmented ones. Moreover, high-LET radiation (fast neutrons) is effective in the inhibition of BHM tumor growth independently on its pigmentation.

Thus, Bomirski hamster and Zeman gerbil melanomas represent a comprehensive set of preclinical models-resistant and sensitive to therapies, allowing to define optimal conditions for radiotherapy such as inhibition of melanogenesis in X-ray therapy or selection of proper radiation, which would efficiently treat tumors independently of the level of pigmentation.

Acknowledgments: This review includes work performed over more than 40 years. Sources of funding are mentioned in the respective cited original manuscripts. KU was a recipient of grant no UMO-2012/07/B/NZ4/01657 from Polish National Science Centre. Faculty of Biochemistry, Biophysics, and Biotechnology of the Jagiellonian University is a partner of the Leading National Research Center (KNOW) supported by the Ministry of Science and Higher Education (Grant KNOW 35p/10/2015 to PMP). Partial support from grants 1R01AR056666-01A2, R21AR066505, and 1R01AR071189-01A1 to AS from NIH and 2014/15/B/NZ4/00751 to AAB from National Science Centre, Poland, is also acknowledged. The graphical abstract contains an illustration element made by Servier Medical Art (https:/ / smart.servier.com/). Authors are grateful to Dr. Radomir Slominski for proofreading the manuscript.

Author Contributions: Martyna Śniegocka prepared illustrations, and performed literature research, Ewa Podgórska managed the references, and performed literature research, Przemysław M. Płonka described the role of melanins and hamster as a model animal, Martyna Elas edited and revised the text, Bożena Romanowska-Dixon described the radiosensitivity of UM tumors, Małgorzata Szczygieł described gerbils as model animals, Zeman UJ90 melanoma results, and prepared a graphical abstract, Michał A. Żmijewski and Mirosława Cichorek described Bomirski hamster melanoma, Anna Markiewicz described UM brachytherapy and proton beam therapy, Anna A. Brożyna described the role of inhibition of melanoma pigmentation, Andrzej T. Stominski delineated the concept of the paper, and described clinical aspects of human skin melanoma and contributed to the section on rodent melanomas, Krystyna Urbańska was responsible for the concept of the paper, described the radiophototherapy, radiosensitivity of BHM, and the proteomic study.

Conflicts of Interest: The authors declare no conflicts of interest. 


\section{References}

1. Urteaga, B.O.; Pack, G.T. On the antiquity of melanoma. Cancer 1966, 19, 607-610. [CrossRef]

2. Slominski, R.M.; Zmijewski, M.A.; Slominski, A.T. The role of melanin pigment in melanoma. Exp. Dermatol. 2015, 24, 258-259. [CrossRef] [PubMed]

3. Bomirski, A.; Dominiczak, T.; Nowinska, L. Spontaneous transplantable melanoma in the golden hamster (Mesocricetus auratus). Acta Unio Int. Contra Cancrum 1962, 18, 178-180. [PubMed]

4. Bomirski, A. Biological Properties of Transplantable Melanomas in the Syrian Hamster during 16 Years of Maintenance by Serial Passages. Habilitation Thesis, Medical School of Gdansk, Gdansk, Poland, 1977.

5. Bomirski, A.; Słominski, A.; Bigda, J. The natural history of a family of transplantable melanomas in hamsters. Cancer Metastasis Rev. 1988, 7, 95-118. [CrossRef] [PubMed]

6. Slominski, A.; Paus, R. Bomirski melanomas: A versatile and powerful model for pigment cell and melanoma research. Int. J. Oncol. 1993, 2, 221-228. [CrossRef] [PubMed]

7. Pajak, S.; Cieszka, K.; Plonka, P.; Lukiewicz, S.; Mihm, M.; Slominski, A. Transplantable melanomas in gerbils (Meriones unguiculatus). I. Origin, morphology and growth rate. Anticancer Res. 1996, 16, 1203-1208. [PubMed]

8. Plonka, P.M.; Slominski, A.T.; Pajak, S.; Urbanska, K. Transplantable melanomas in gerbils (Meriones unguiculatus). II: Melanogenesis. Exp. Dermatol. 2003, 12, 356-364. [CrossRef] [PubMed]

9. Billingham, R.E.; Silvers, W.K. The melanocytes of mammals. Q. Rev. Biol. 1960, 35, 1-40. [CrossRef] [PubMed]

10. Van Den Bossche, K.; Naeyaert, J.-M.; Lambert, J. The Quest for the Mechanism of Melanin Transfer. Traffic 2006, 7, 769-778. [CrossRef] [PubMed]

11. Lazova, R.; Pawelek, J.M. Why do melanomas get so dark? Exp. Dermatol. 2009, 18, 934-938. [CrossRef] [PubMed]

12. Lazova, R.; Klump, V.; Pawelek, J. Autophagy in cutaneous malignant melanoma. J. Cutan. Pathol. 2010, 37 , 256-268. [CrossRef] [PubMed]

13. Lembo, S.; Di Caprio, R.; Micillo, R.; Balato, A.; Monfrecola, G.; Panzella, L.; Napolitano, A. Lightindependent pro-inflammatory and pro-oxidant effects of purified human hair melanins on keratinocyte cell cultures. Exp. Dermatol. 2017, 26, 592-594. [CrossRef] [PubMed]

14. Płonka, P.M.; Picardo, M.; Slominski, A.T. Does melanin matter in the dark? Exp. Dermatol. 2017, 26, 595-597. [CrossRef] [PubMed]

15. Slominski, A.; Paus, R.; Mihm, M.C. Inhibition of melanogenesis as an adjuvant strategy in the treatment of melanotic melanomas: Selective review and hypothesis. Anticancer Res. 1998, 18, 3709-3716. [PubMed]

16. Brożyna, A.A.; Jóźwicki, W.; Carlson, J.A.; Slominski, A.T. Melanogenesis affects overall and disease-free survival in patients with stage III and IV melanoma. Hum. Pathol. 2013, 44, 2071-2074. [CrossRef] [PubMed]

17. Englaro, W.; Rezzonico, R.; Durand-Clement, M.; Lallemand, D.; Ortonne, J.-P.; Ballotti, R. Mitogen-activated protein kinase pathway and AP-1 are activated during cAMP-induced melanogenesis in B-16 melanoma cells. J. Biol. Chem. 1995, 270, 24315-24320. [CrossRef] [PubMed]

18. Ortonne, J.-P.; Ballotti, R. Melanocyte biology and melanogenesis: What's new? J. Dermatol. Treat. 2000, 11, 15-26. [CrossRef]

19. Slominski, A.T.; Tobin, D.J.; Shibahara, S.; Wortsman, J. Melanin Pigmentation in Mammalian Skin and Its Hormonal Regulation. Physiol. Rev. 2004, 84, 1155-1228. [CrossRef] [PubMed]

20. Spagnolo, F.; Queirolo, P. Upcoming strategies for the treatment of metastatic melanoma. Arch. Dermatol. Res. 2012, 304, 177-184. [CrossRef] [PubMed]

21. Jean, D.; Bar-Eli, M. Regulation of tumor growth and metastasis of human melanoma by the CREB transcription factor family. Mol. Cell. Biochem. 2000, 212, 19-28. [CrossRef] [PubMed]

22. Buscà, R.; Bertolotto, C.; Ortonne, J.-P.; Ballotti, R. Inhibition of the phosphatidylinositol 3-kinase/p70(S6)-kinase pathway induces B16 melanoma cell differentiation. J. Biol. Chem. 1996, 271, 31824-31830. [CrossRef] [PubMed]

23. Curtin, J.A.; Busam, K.; Pinkel, D.; Bastian, B.C. Somatic activation of KIT in distinct subtypes of melanoma. J. Clin. Oncol. 2006, 24, 4340-4346. [CrossRef]

24. Albino, A.P.; Le Strange, R.; Oliff, A.I.; Furth, M.E.; Old, L.J. Transforming ras genes from human melanoma: A manifestation of tumour heterogeneity? Nature 1984, 308, 69-72. [CrossRef] [PubMed] 
25. Padua, R.A.; Barrass, N.; Currie, G.A. A novel transforming gene in a human malignant melanoma cell line. Nature 1984, 311, 671-673. [CrossRef] [PubMed]

26. Davies, H.; Bignell, G.R.; Cox, C.; Stephens, P.; Edkins, S.; Clegg, S.; Teague, J.; Woffendin, H.; Garnett, M.J.; Bottomley, W.; et al. Mutations of the BRAF gene in human cancer. Nature 2002, 417, 949-954. [CrossRef] [PubMed]

27. Hingorani, S.R.; Jacobetz, M.A.; Robertson, G.P. Suppression of BRAFV599E in Human Melanoma Abrogates Transformation Suppression of BRAF V599E in Human Melanoma Abrogates Transformation 1. Cancer Res. 2003, 63, 5198-5202. [PubMed]

28. Wellbrock, C.; Ogilvie, L.; Hedley, D.; Karasarides, M.; Martin, J.; Niculescu-Duvaz, D.; Springer, C.J.; Marais, R. V599E B-RAF is an Oncogene in Melanocytes. Cancer Res. 2004, 64, 2338-2342. [CrossRef] [PubMed]

29. Smalley, K.S.M. Understanding Melanoma Signaling Networks as the Basis for Molecular Targeted Therapy. J. Investig. Dermatol. 2010, 130, 28-37. [CrossRef] [PubMed]

30. Slominski, A.; Pawelek, J. Animals under the sun: Effects of ultraviolet radiation on mammalian skin. Clin. Dermatol. 1998, 16, 503-515. [CrossRef]

31. Wood, J.M.; Jimbow, K.; Boissy, R.E.; Slominski, A.; Plonka, P.M.; Slawinski, J.; Wortsman, J.; Tosk, J. What's the use of generating melanin? Exp. Dermatol. 1999, 8, 153-164. [CrossRef] [PubMed]

32. Meredith, P.; Sarna, T. The physical and chemical properties of eumelanin. Pigment Cell Res. 2006, 19, 572-594. [CrossRef] [PubMed]

33. Meredith, P.; Powell, B.J.; Riesz, J.; Nighswander-Rempel, S.P.; Pederson, M.R.; Moore, E.G. Towards structure-property-function relationships for eumelanin. Soft Matter 2006, 2, 37-44. [CrossRef]

34. D'Ischia, M.; Napolitano, A.; Pezzella, A.; Meredith, P.; Sarna, T. Chemical and structural diversity in eumelanins: Unexplored bio-optoelectronic materials. Angew. Chem. Int. Ed. 2009, 48, 3914-3921. [CrossRef] [PubMed]

35. Commoner, B.; Townsend, J.; Pake, G.E. Free radicals in biological materials. Nature 1954, 174, 689-691. [CrossRef] [PubMed]

36. Blois, M.S.; Zahlan, A.B.; Maling, J.E. Electron Spin Resonance Studies on Melanin. Biophys. J. 1964, 4, 471-490. [CrossRef]

37. Sarna, T.; Pilas, B.; Land, E.J.; Truscott, T.G. Interaction of radicals from water radiolysis with melanin. BBA Gen. Subj. 1986, 883, 162-167. [CrossRef]

38. Sarna, T.; Plonka, P.M. Biophysical Studies of Melanin. Biomed. EPR Part A Free Radic. Met. Med. Physiol. 2005, 125-146. [CrossRef]

39. Sarna, T.; Hyde, J.; Swartz, H. Ion-exchange in melanin: An electron spin resonance study with lanthanide probes. Science 1976, 1132-1134. [CrossRef]

40. Zecca, L.; Swartz, H. Total and paramagnetic metals in human substantia nigra and its neuromelanin. J. Neural Transm. 1993, 5, 203-213. [CrossRef]

41. Korytowski, W.; Pilas, B.; Sarna, T.; Kalyanaraman, B. Photoinduced generation of hydrogen peroxide and hydroxyl radicals in melanins. Photochem. Photobiol. 1987, 45, 185-190. [CrossRef] [PubMed]

42. Borovanský, J.; Elleder, M. Melanosome Degradation: Fact or Fiction. Pigment Cell Res. 2003, 16, $280-286$. [CrossRef] [PubMed]

43. Samokhvalov, A.; Hong, L.; Liu, Y.; Garguilo, J.; Nemanich, R.J.; Edwards, G.S.; Simon, J.D. Oxidation potentials of human eumelanosomes and pheomelanosomes. Photochem. Photobiol. 2005, 81, 145-148. [CrossRef] [PubMed]

44. Simon, J.D.; Peles, D.N. The red and the black. Acc. Chem. Res. 2010, 43, 1452-1460. [CrossRef] [PubMed]

45. ElObeid, A.S.; Kamal-Eldin, A.; Abdelhalim, M.A.K.; Haseeb, A.M. Pharmacological Properties of Melanin and its Function in Health. Basic Clin. Pharmacol. Toxicol. 2017, 120, 515-522. [CrossRef] [PubMed]

46. Lukiewicz, S.; Pilas, B.; Nowicka, J. Molecular and cellular basis of different radiosensitivity in pigmented and non-pigmented hamster melanoma-cells. In Phenotypic Expression in Pigmented Cells; Seiji, H., Ed.; University of Tokyo Press: Tokyo, Japan, 1981; pp. 647-653.

47. Lukiewicz, S. Interference with endogenous radioprotectors as a method of radiosensitization. In IAEA's Modification of Radiosensitivity of Biological Systems; International Atomic Energy Agency: Vienna, Austria, 1976.

48. Sarna, T.; Dulęba, A.; Korytowski, W.; Swartz, H. Interaction of melanin with oxygen. Arch. Biochem. Biophys. 1980, 200, 140-148. [CrossRef] 
49. Pathak, M.A.; Riley, F.J.; Fitzpatrick, T.B.; Curwen, W.L. Melanin formation in human skin induced by long-wave ultra-violet and visible light. Nature 1962, 193, 148-150. [CrossRef] [PubMed]

50. Kobayashi, N.; Nakagawa, A.; Muramatsu, T.; Yamashina, Y.; Shirai, T.; Hashimoto, M.W.; Ishigaki, Y.; Ohnishi, T.; Mori, T. Supranuclear melanin caps reduce ultraviolet induced DNA photoproducts in human epidermis. J. Investig. Dermatol. 1998, 110, 806-810. [CrossRef] [PubMed]

51. Schweitzer, A.D.; Howell, R.C.; Jiang, Z.; Bryan, R.A.; Gerfen, G.; Chen, C.C.; Mah, D.; Cahill, S.; Casadevall, A.; Dadachova, E. Physico-chemical evaluation of rationally designed melanins as novel nature-inspired radioprotectors. PLOS ONE 2009, 4, e7229. [CrossRef] [PubMed]

52. Turick, C.E.; Ekechukwu, A.A.; Milliken, C.E.; Casadevall, A.; Dadachova, E. Gamma radiation interacts with melanin to alter its oxidation-reduction potential and results in electric current production. Bioelectrochemistry 2011, 82, 69-73. [CrossRef] [PubMed]

53. Rózanowska, M.; Sarna, T.; Land, E.J.; Truscott, T.G. Free radical scavenging properties of melanin interaction of eu- and pheo-melanin models with reducing and oxidising radicals. Free Radic. Biol. Med. 1999, 26, 518-525. [CrossRef] [PubMed]

54. Land, E.J.; Ramsden, C.A.; Riley, P.A. Quinone Chemistry and Melanogenesis. Methods Enzymol. 2004, 378, 88-109. [CrossRef] [PubMed]

55. Pey, A.L.; Martinez, A.; Charubala, R.; Maitland, D.J.; Teigen, K.; Calvo, A.; Pfleiderer, W.; Wood, J.M.; Schallreuter, K.U. Specific interaction of the diastereomers $7(\mathrm{R})$ - and 7(S)-tetrahydrobiopterin with phenylalanine hydroxylase: Implications for understanding primapterinuria and vitiligo. FASEB J. 2006, 20, 2130-2132. [CrossRef] [PubMed]

56. Gallez, B.; Neveu, M.A.; Danhier, P.; Jordan, B.F. Manipulation of tumor oxygenation and radiosensitivity through modification of cell respiration. A critical review of approaches and imaging biomarkers for therapeutic guidance. Biochim. Biophys. Acta Bioenergy 2017, 1858, 700-711. [CrossRef] [PubMed]

57. Grossi, G.F.; Durante, M.; Gialanella, G.; Pugliese, M.; Mosse, I. Effects of melanin on high- and low-linear energy transfer (LET) radiation response of human epithelial cells. Radiat. Environ. Biophys. 1998, 37, $63-67$. [CrossRef] [PubMed]

58. Sava, V.; Mosquera, D.; Song, S.; Cardozo-Pelaez, F.; Sánchez-Ramos, J.R. Effects of melanin and manganese on DNA damage and repair in PC12-derived neurons. Free Radic. Biol. Med. 2004, 36, 1144-1154. [CrossRef] [PubMed]

59. Sharma, A.; Gaidamakova, E.K.; Grichenko, O.; Matrosova, V.Y.; Hoeke, V.; Klimenkova, P.; Conze, I.H.; Volpe, R.P.; Tkavc, R.; Gostinčar, C.; et al. Across the tree of life, radiation resistance is governed by antioxidant $\mathrm{Mn}^{2+}$, gauged by paramagnetic resonance. Proc. Natl. Acad. Sci. USA 2017, 114, 201713608. [CrossRef] [PubMed]

60. Murphy, M.R. History of the Capture and Domestication of the Syrian Golden Hamster (Mesocricetus auratus Waterhouse). In The Hamster; Springer: Boston, MA, USA, 1985; pp. 3-20.

61. McGuire, K.L.; Duncan, W.R.; Tucker, P.W. Syrian hamster DNA shows limited polymorphism at class I-like loci. Immunogenetics 1985, 22, 257-268. [CrossRef] [PubMed]

62. Silvers, W.K.; Gasser, D.L.; Murphy, M.R. Number of Histocompatibility Loci in Syrian Hamsters. J. Immunol. 1975, 115, 1309-1311. [PubMed]

63. Valentine, H.; Daugherity, E.K.; Singh, B.; Maurer, K.J. The Experimental Use of Syrian Hamsters. In The Laboratory Rabbit, Guinea Pig, Hamster, and Other Rodents; Elsevier: Amsterdam, The Netherlands, 2012; pp. 875-906. ISBN 9780123809209.

64. Wahl-Jensen, V.; Bollinger, L.; Safronetz, D.; de Kok-Mercado, F.; Scott, D.; Ebihara, H. Use of the Syrian Hamster as a New Model of Ebola Virus Disease and Other Viral Hemorrhagic Fevers. Viruses 2012, 4, 3754-3784. [CrossRef] [PubMed]

65. Adler, S. Origin of the Golden Hamster Cricetus auratus as a Laboratory Animal. Nature 1948, 162, $256-257$. [CrossRef] [PubMed]

66. Chorobik, P.; Czaplicki, D.; Ossysek, K.; Bereta, J. Salmonella and cancer: From pathogens to therapeutics. Acta Biochim. Pol. 2013, 60, 285-297. [PubMed]

67. Slominski, A.; Wortsman, J.; Plonka, P.M.; Schallreuter, K.U.; Paus, R.; Tobin, D.J. Hair follicle pigmentation. J. Investig. Dermatol. 2005, 124, 13-21. [CrossRef] [PubMed]

68. Pour, P.; Althoff, J.; Salmasi, S.Z.; Stepan, K. Spontaneous Tumors and Common Diseases in Three Types of Hamsters2. JNCI J. Natl. Cancer Inst. 1979, 63, 797-811. [CrossRef] [PubMed] 
69. Kusewitt, D.; Ley, R. Animal Models of Melanoma. Cancer Surv. 1996, 26, 35-70. [CrossRef] [PubMed]

70. Ghadially, F.N.; Barker, J.F. The histogenesis of experimentally induced melanotic tumours in the Syrian hamster (Cricetus auratus). J. Pathol. Bacteriol. 1960, 79, 263-271. [CrossRef] [PubMed]

71. Fortner, J.G.; Allen, A.C. Hitherto Unreported Malignant Melanomas in the Syrian Hamster: An Experimental Counterpart of the Human Malignant Melanomas. Cancer Res. 1958, 18, 98-104.

72. Homburger, F. Chemical carcinogenesis in the Syrian golden hamster. Cancer 1969, 23, 313-338. [CrossRef]

73. Pawlowski, A.; Lea, P.J. Nevi and melanoma induced by chemical carcinogens in laboratory animals: Similarities and differences with human lesions. J. Cutan. Pathol. 1983, 10, 81-110. [CrossRef] [PubMed]

74. Bardeesy, N.; Wong, K.K.; DePinho, R.A.; Chin, L. Animal models of melanoma: Recent advances and future prospects. Adv. Cancer Res. 2000, 79, 123-156. [CrossRef] [PubMed]

75. Greene, H.S.N. A Spontaneous Melanoma in the Hamster with a Propensity for Amelanotic Alteration and Sarcomatous Transformation during Transplantation. Cancer Res. 1958, 18, 422-425. [PubMed]

76. Burgess, S.E.; Chang, S.; Svitra, P.; Driller, J.; Lizzi, F.L.; Coleman, D.J. Effect of hyperthermia on experimental choroidal melanoma. Br. J. Ophthalmol. 1985, 69, 854-860. [CrossRef] [PubMed]

77. Franken, K.A.P.; van Delft, J.L.; Dubbelman, T.M.A. R.; de Wolff-Rouendaal, D.; Oosterhuis, J.A.; Star, W.M.; Marijnissen, H.P.A. Hematoporphyrin derivative photoradiation treatment of experimental malignant melanoma in the anterior chamber of the rabbit. Curr. Eye Res. 1985, 4, 641-654. [CrossRef] [PubMed]

78. Fortner, J.G. Spontaneous tumors, including gastrointestinal neoplasms and malignant melanomas, in the syrian hamster. Cancer 1957, 10, 1153-1156. [CrossRef]

79. Ott, F. Hamster melanoma M Mel 1 as an ascites tumor. I. Comparison of the various melanoma of the Syrian hamster and the mice. Detailed description of the form of ascites. Arch. Klin. Exp. Dermatol. 1969, 234, 362-383. [CrossRef] [PubMed]

80. Ott, F. Hamster melanoma M Mel 1 as an ascietes tumor. II. Research. Arch. Klin. Exp. Dermatol. 1969, 234, 384-398. [CrossRef] [PubMed]

81. Slominski, A.; Costantino, R. L-tyrosine induces tyrosinase expression via a posttranscriptional mechanism. Experientia 1991, 47, 721-724. [CrossRef] [PubMed]

82. Slominski, A.T.; Carlson, J.A. Melanoma resistance: A bright future for academicians and a challenge for patient advocates. Mayo Clin. Proc. 2014, 89, 429-433. [CrossRef] [PubMed]

83. Slominski, A.; Kobzdej, D. Transplantability of Bomirski melanomas in Syrian hamsters. Neoplasma 1983, 30, 51-56. [PubMed]

84. Scislowski, P.W.D. Biochemical characterization of three hamster melanoma variants. II. Glycolysis and oxygen consumption. Int. J. Biochem. 1984, 16, 327-331. [CrossRef]

85. Słomiński, A. Rapid melanization of Bomirski amelanotic melanoma cells in cell culture. Biosci. Rep. 1983, 3, 189-194. [CrossRef] [PubMed]

86. Słomiński, A.; Scisłowski, P.W.; Bomirski, A. Tyrosinase activity in primary cell culture of amelanotic melanoma cells. Biosci. Rep. 1983, 3, 1027-1034. [CrossRef] [PubMed]

87. Słomiński, A. Some properties of Bomirski Ab amelanotic melanoma cells, which underwent spontaneous melanization in primary cell culture. J. Cancer Res. Clin. Oncol. 1985, 109, 29-37. [CrossRef] [PubMed]

88. Słomiński, A.; Bomirski, A. Phenotypic changes of Ab hamster melanoma during long-term culture. Anticancer Res. 1985, 5, 403-410. [PubMed]

89. Bomirski, A.; Słomiński, A. Ultrastructural aspects of melanization of hamster Ab amelanotic melanoma in primary cell culture. Acta Derm.-Venereol. 1986, 66, 520-538. [PubMed]

90. Słomiński, A.; Bomirski, A.; Scisłowski, P.W.; Zołnierowicz, S. Effects of actinomycin D and cycloheximide on the increase in tyrosinase activity of hamster amelanotic melanoma cells in vitro. Biosci. Rep. 1984, 4, 1059-1064. [CrossRef] [PubMed]

91. Slominski, A.; Daniel, P. L-Dopa binding sites in rodent melanoma cells. Biochim. Biophys. Acta Mol. Basis Dis. 1992, 1139, 324-328. [CrossRef]

92. Slominski, A.; Kim, T.K.; Brozyna, A.A.; Janjetovic, Z.; Brooks, D.L.P.; Schwab, L.P.; Skobowiat, C.; Jóźwicki, W.; Seagroves, T.N. The role of melanogenesis in regulation of melanoma behavior: Melanogenesis leads to stimulation of HIF-1 $\alpha$ expression and HIF-dependent attendant pathways. Arch. Biochem. Biophys. 2014, 563, 79-93. [CrossRef] [PubMed]

93. Slominski, A.; Pawelek, J. MSH binding in Bomirski amelanotic hamster melanoma cells is stimulated by L-tyrosine. Biosci. Rep. 1987, 7, 949-954. [CrossRef] [PubMed] 
94. Slominski, A.; Moellmann, G.; Kuklinska, E.; Bomirski, A.; Pawelek, J. Positive regulation of melanin pigmentation by two key substrates of the melanogenic pathway, L-tyrosine and L-dopa. J. Cell Sci. 1988, 89.

95. Slominski, A. L-tyrosine induces synthesis of melanogenesis related proteins. Life Sci. 1989, 45, 1799-1803. [CrossRef]

96. Slominski, A.; Jastreboff, P.; Pawelek, J. L-tyrosine stimulates induction of tyrosinase activity by MSH and reduces cooperative interactions between MSH receptors in hamster melanoma cells. Biosci. Rep. 1989, 9, 579-586. [CrossRef] [PubMed]

97. Slominski, A.; Moellmann, G.; Kuklinska, E. MSH inhibits growth in a line of amelanotic hamster melanoma cells and induces increases in cyclic AMP levels and tyrosinase activity without inducing melanogenesis. J. Cell Sci. 1989, 92, 551-554. [PubMed]

98. Slominski, A.; Moellmann, G.; Kuklinska, E. L-Tyrosine, L-DOPA, and Tyrosinase as Positive Regulators of the Subcellular Apparatus of Melanogenesis in Bomirski Ab Amelanotic Melanoma Cells. Pigment Cell Res. 1989, 2, 109-116. [CrossRef] [PubMed]

99. Howe, J.; Costantino, R.; Slominski, A. On the putative mechanism of induction and regulation of melanogenesis by L-tyrosine. Acta Derm.-Venereol. 1991, 71, 150-152. [PubMed]

100. Slominski, A.; Costantino, R. Molecular mechanism of tyrosinase regulation by L-DOPA in hamster melanoma cells. Life Sci. 1991, 48, 2075-2079. [CrossRef]

101. Slominski, A.; Friedrich, T. L-DOPA Inhibits In Vitro Phosphorylation of Melanoma Glycoproteins. Pigment Cell Res. 1992, 5, 396-399. [CrossRef] [PubMed]

102. Slominski, A. L-tyrosine-binding proteins on melanoma cells. In Vitro Cell. Dev. Biol. Anim. 1991, $27,735-738$. [CrossRef]

103. Cichorek, M.; Kozlowska, K.; Bryl, E. The activity of caspases in spontaneous and camptothecin-induced death of melanotic and amelanotic melanoma cell. Cancer Biol. Ther. 2007, 6, 346-353. [CrossRef] [PubMed]

104. Cichorek, M. Camptothecin-induced death of amelanotic and melanotic melanoma cells in different phases of cell cycle. Neoplasma 2011, 58, 227-234. [CrossRef] [PubMed]

105. Pajak, S.; Subczynski, W.; Panz, T.; Lukiewicz, S. Rate of oxygen consumption of hamster melanoma cells as a factor influencing their radioresistance. Folia Histochem. Cytochem. 1980, 18, 33-40.

106. Scisłowski, P.W.; Słomiński, A.; Bomirski, A.; Zydowo, M. Metabolic characterization of three hamster melanoma variants. Neoplasma 1985, 32, 593-598. [PubMed]

107. Scisłowski, P.W.; Słominski, A. The role of NADP-dependent dehydrogenases in hydroxylation of tyrosine in hamster melanoma. Neoplasma 1983, 30, 239-243. [PubMed]

108. Li, W.; Slominski, R.; Slominski, A.T. High-resolution magic angle spinning nuclear magnetic resonance analysis of metabolic changes in melanoma cells after induction of melanogenesis. Anal. Biochem. 2009, 386, 282-284. [CrossRef] [PubMed]

109. Cichorek, M.; Kozłowska, K.; Bryl, E. Mitochondrial transmembrane potential in spontaneous and camptothecin-induced apoptosis of melanotic and amelanotic melanoma cells. Neoplasma 2007, 54, 29-36. [PubMed]

110. Bomirski, A.; Zawrocka-Wrzolkowa, T.; Pautsch, F. Electron microscopic studies on transplantable melanotic and amelanotic melanomas in hamsters. Arch. Dermatol. Forsch. 1973, 246, 284-298. [CrossRef] [PubMed]

111. Kozlowska, K.; Bomirski, A. Comparison of the surface glycoprotein components in the isolated cells of hamster melanotic and amelanotic melanomas. Arch. Dermatol. 1976, 256, 197-203. [CrossRef]

112. Kozłowska, K.; Żurawska-Czupa, B. Heterogeneity of the surface material in isolated cells of transplantable hamster melanomas. Cancer Res. 1983, 43, 1168-1171. [PubMed]

113. Kozłowska, K.; Nowak, J.; Kwiatkowski, B.; Cichorek, M. ESR study of plasmatic membrane of the transplantable melanoma cells in relation to their biological properties. Exp. Toxicol. Pathol. 1999, 51, 89-92. [CrossRef]

114. Kozłowska, K.; Witkowski, J.M.; Zarzeczna, M.; Cichorek, M. Diversity of the plasma membrane properties of transplantable hamster melanomas with regard to the expression of P-glycoprotein. Folia Histochem. Cytobiol. 1999, 37, 173-177. [PubMed]

115. Ren, S.; Slominski, A.; Yu, R.K. Glycosphingolipids in Bomirski Transplantable Melanomas in Hamsters. Cancer Res. 1989, 49, 7051-7056. [PubMed] 
116. Ren, S.; Ariga, T.; Scarsdale, J.N.; Zhang, Y.; Slominski, A.; Livingston, P.O.; Ritter, G.; Kushi, Y.; Yu, R.K. Characterization of a hamster melanoma-associated ganglioside antigen as 7-O-acetylated disialoganglioside GD3. J. Lipid Res. 1993, 34, 1565-1572. [PubMed]

117. Grossniklaus, H.E.; Dithmar, S.; Albert, D.M. Animal models of uveal melanoma. Melanoma Res. 2000, 10, 195-211. [CrossRef]

118. Kozłowska, K.; Zurawska-Czupa, B. Comparison of the antigenicity of melanotic and amelanotic melanoma cells after the release of surface glycoproteins by trypsin. Arch. Immunol. 1980, 28, 641-644.

119. Kozlowska, K.; Zurawska-Czupa, B.; Mierzewski, P.; Kostulak, A. Use of the macrophage migration inhibition test to evaluate antigenic differences in golden hamster transplantable melanomas. Int. J. Cancer 1980, 26, 211-215. [CrossRef] [PubMed]

120. Kozłowska, K.; Kostulak, A. Comparative analysis of surface antigens of transplantable melanoma in hamsters. I. Studies on serological reactivity of sera with isolated melanocytes by using the. Arch. Immunol. 1984, 32, 59-66.

121. Kozlowska, K.; Cichorek, M.; Zarzeczna, M.; Wojcik, S. Expression of CD44 on two lines of transplantable melanoma cells-relationship with cytokine secretion and tumor progression. Folia Histochem. Cytobiol. 2004, 42, 29-34. [PubMed]

122. Wachulska, M.; Kozłowska, K.; Cichorek, M. The DNA ploidy and proliferative activity of transplantable melanoma cells in regard to their secretory function. Neoplasma 2005, 52, 280-286. [PubMed]

123. Słomiński, A.; Ścisłowski, P.W.D.; Bomirski, A. Biochemical characterization of three hamster melanoma variants-I. Tyrosinase activity and melanin content. Int. J. Biochem. 1984, 16, 323-326. [CrossRef]

124. Slominski, A.; Costantino, R.; Howe, J.; Moellmann, G. Molecular mechanism governing melanogenesis in hamster melanomas: Relative abundance of tyrosinase and catalase-B (gp 75). Anticancer Res. 1991, 11, 257-262. [PubMed]

125. Woźniak, A.; Drewa, T.; Drewa, O.; Woźniak, B.; Schachtschabel, D.O. Activity of antioxidant enzymes and concentrations of thiobarbituric acid reactive substances (TBARS) in melanotic and amelanotic Bomirski melanoma tissues in the golden hamster (Mesocricetus auratus, Waterhouse). Neoplasma 2002, 49, 401-404. [PubMed]

126. Bomirski, A.; Wrzolkowa, T.; Arendarczyk, M.; Bomirska, M.; Kuklinska, E.; Slominski, A.; Moellmann, G. Pathology and Ultrastructural Characteristics of a Hypomelanotic Variant of Transplantable Hamster Melanoma With Elevated Tyrosinase Activity. J. Investig. Dermatol. 1987, 89, 469-473. [CrossRef] [PubMed]

127. Słomiński, A.; Ścisłowski, P.W.D.; Arendarczyk, M. Effect of tissue selection on melanization of MI hamster melanoma. Neoplasma 1984, 31, 551-556. [PubMed]

128. Pajak, S. Role of Endogenous Radioprotectors in Radioresistance of the Melanotic and Amelanotic form of Bomirski Melanoma. Ph.D. Thesis, Jagiellonian University, Kraków, Poland, 1980.

129. Gurbiel, R. Oxygen Role in Radiosensitivity of Pigmented Bomirski Hamster Melanoma. Ph.D. Thesis, Jagiellonian University, Kraków, Poland, 1984. (In Polish)

130. Urbanska, K. Radiosensitization of Pigmented Cells and Animal Melanoma Tumors to Ionizing Radiation. Habilitation Thesis, Jagiellonian University, Kraków, Poland, 2000. (In Polish)

131. Cao, J.; Jager, M.J. Animal Eye Models for Uveal Melanoma. Ocul. Oncol. Pathol. 2015, 1, 141-150. [CrossRef] [PubMed]

132. Schuitmaker, J.J.; Vrensen, G.F.J.M.; Van Delft, J.L.; De Wolff-Rouendaal, D.; Dubbelman, T.M.A.R.; De Wolf, A. Morphologic effects of bacteriochlorin a and light in vivo on intraocular melanoma. Investig. Ophthalmol. Vis. Sci. 1991, 32, 2683-2688.

133. Römer, T.J.; van Delft, J.L.; de Wolff-Rouendaal, D.; Jager, M.J. Hamster Greene melanoma implanted in the anterior chamber of a rabbit eye: A reliable tumor model? Ophthalmic Res. 1992, 24, 119-124. [CrossRef] [PubMed]

134. Hu, L.K.; Huh, K.; Gragoudas, E.S.; Young, L.H. Establishment of pigmented choroidal melanomas in a rabbit model. Retina 1994, 14, 264-269. [CrossRef] [PubMed]

135. Romanowska, B.; Kukiełczak, B.; Bryk, J.; Mirkiewicz-Sieradzka, B.; Heitzmann, J.; Lukiewicz, S. New technique for implanting Bomirski melanoma into the anterior chamber of Syrian hamster eyes. Klin. Oczna 1995, 97, 324-327. [PubMed] 
136. Urbanska, K.; Romanowska-Dixon, B.; Elas, M.; Pajak, S.; Paziewski, E.; Bryk, J.; Kukielczak, B.; Slominski, A.; Zygulska-Mach, H.; Lukiewicz, S. Experimental ruthenium plaque therapy of amelanotic and melanotic melanomas in the hamster eye. Melanoma Res. 2000, 10, 26-35. [CrossRef] [PubMed]

137. Romanowska-Dixon, B.; Urbanska, K.; Elas, M.; Pajak, S.; Zygulska-Mach, H.; Miodonski, A. Angiomorphology of the pigmented Bomirski melanoma growing in hamster eye. Ann. Anat. 2001, 183, 559-565. [CrossRef]

138. Romanowska-Dixon, B.; Elas, M.; Swakoń, J.; Sowa, U.; Ptaszkiewicz, M.; Szczygieł, M.; Krzykawska, M.; Olko, P.; Urbańska, K. Metastasis inhibition after proton beam, $\beta$ - and $\gamma$-irradiation of melanoma growing in the hamster eye. Acta Biochim. Pol. 2013, 60, 307-311. [PubMed]

139. Ogata, T.; Teshima, T.; Kagawa, K.; Hishikawa, Y.; Takahashi, Y.; Kawaguchi, A.; Suzumoto, Y.; Nojima, K.; Furusawa, Y.; Matsuura, N. Particle Irradiation Suppresses Metastatic Potential of Cancer Cells Particle Irradiation Suppresses Metastatic Potential of Cancer Cells. Cancer Res. 2005, 65, 113-120. [PubMed]

140. Takahashi, Y.; Teshima, T.; Kawaguchi, N.; Hamada, Y.; Mori, S.; Madachi, A.; Ikeda, S.; Mizuno, H.; Ogata, T.; Nojima, K.; et al. Heavy ion irradiation inhibits in vitro angiogenesis even at sublethal dose. Cancer Res. 2003, 63, 4253-4257. [PubMed]

141. Kukielczak, B.; Cieszka, K.; Matuszak, Z. Experimental photodynamic therapy of Bomirski hamster melanoma using merocyanine 540 and visible light. Curr Top. Biophys. 1995, 19, 66-70.

142. Kukielczak, B.; Romanowska, B.; Bryk, J. Gamma radiation and MC540 photosensitization of melanoma in the hamster's eye. Melanoma Res. 1999, 9, 115-124. [CrossRef] [PubMed]

143. ITIS Integrated Taxonomic Information System. Available online: https://www.itis.gov/ (accessed on 11 October 2017).

144. Gulotta, E.F. Meriones unguiculatus. Mamm. Species 1971, 1. [CrossRef]

145. Agren, G.; Zhou, Q.; Zhong, W. Ecology and social behaviour of Mongolian gerbils, Meriones unguiculatus, at Xilinhot, Inner Mongolia, China. Anim. Behav. 1989, 37, 11-27. [CrossRef]

146. Susić, V.; Masirević, G. Sleep patterns in the Mongolian gerbil, Meriones unguiculatus. Physiol. Behav. 1986, 37, 257-261. [CrossRef]

147. Fisher, M.F.; Llewellyn, G.C. The Mongolian Gerbil: Natural History, Care, and Maintenance. Source Am. Biol. Teach. 1978, 40, 557-560.

148. Yoshimura, H. Behavioral characteristics of scent marking behavior in the Mongolian gerbil (Meriones unguiculatus). Exp. Anim. 1981, 30, 107-112. [CrossRef]

149. Cheal, M. The gerbil: A unique model for research on aging. Exp. Aging Res. 1986, 12, 3-21. [CrossRef] [PubMed]

150. Loskota, W.J.; Lomax, P.; Rich, S.T. The Gerbil as a Model for the Study of the Epilepsies. Epilepsia 1974, 15, 109-119. [CrossRef] [PubMed]

151. Nakamura, Y.; Nakaya, T.; Hagiwara, K.; Momiyama, N.; Kagawa, Y.; Taniyama, H.; Ishihara, C.; Sata, T.; Kurata, T.; Ikuta, K. High susceptibility of Mongolian gerbil (Meriones unguiculatus) to Borna disease virus. Vaccine 1999, 17, 480-489. [CrossRef]

152. Anderson, G.W.; Slone, T.W.; Peters, C.J. Vfrology The gerbil, Meriones unguiculatus, a model for Rift Valley fever viral encephalitis. Arch. Virol. 1988, 102, 187-196. [CrossRef] [PubMed]

153. Matsuzaki, T.; Yasuda, Y.; Nonaka, S. The Genetics of Coat Colors in the Mongolian Gerbil (Meriones unguiculatus). Exp. Anim. 1989, 38, 337-341. [CrossRef]

154. Gray-Allan, P.; Wong, R. Influence of coat color genes on seizure behavior in Mongolian gerbils. Behav. Genet. 1990, 20, 481-485. [CrossRef] [PubMed]

155. Benedito, E.; Jiménez-Cervantes, C.; Pérez, D.; Cubillana, J.D.; Solano, F.; Jiménez-Cervantes, J.; Meyer Zum Gottesberge, A.M.; Lozano, J.A.; García-Borrón, J.C. Melanin formation in the inner ear is catalyzed by a new tyrosine hydroxylase kinetically and structurally different from tyrosinase. Biochim. Biophys. Acta Gen. Subj. 1997, 1336, 59-72. [CrossRef]

156. Handler, A.H.; Magalini, S.I.; Pav, D. Oncogenic Studies on the Mongolian Gerbil. Cancer Res. 1966, 26, 844-847.

157. Meckley, P.E.; Zwicker, G.M. Naturally-Occurring Neoplasms in the Mongolian Gerbil, Meriones Unguiculatus. Lab. Anim. 1979, 13, 203-206. [CrossRef] [PubMed]

158. Shumaker, R.C.; Paik, S.K.; Houser, W.D. Tumors in Gerbillinae: A literature review and report of a case. Lab. Anim. Sci. 1974, 24, 688-690. [PubMed] 
159. Naito, M.; Aoyama, H.; Fujioka, Y.; Ito, A. Induction of Gliomas in Mongolian Gerbils (Meriones unguiculatus) Following Neonatal Administration of N-Ethyl-N-nitrosourea2. JNCI J. Natl. Cancer Inst. 1985, 75, 581-587. [CrossRef] [PubMed]

160. Kleihues, P.; Bücheler, J.; Riede, U.N. Selective Induction of Melanomas in Gerbils (Meriones unguiculatus) Following Postnatal Administration of N-Ethyl-N-nitrosourea2. JNCI J. Natl. Cancer Inst. 1978, 61, 859-863. [CrossRef] [PubMed]

161. Yukawa, M.; Onodera, T.; Suzuki, K.; Yokomizo, Y.; Suzuki, M.; Mochizuki, K. Impairment of macrophage function in Mongolian gerbils. Vet. Immunol. Immunopathol. 1992. [CrossRef]

162. Karavodin, L.M.; Ash, L.R. Weak graft-versus-host response in the Mongolian gerbil (Meriones unguiculatus). Lab. Anim. Sci. 1977, 27, 1035-1036. [PubMed]

163. Karavodin, L.M.; Ash, L.R. Weak mixed lymphocyte culture response in the Mongolian gerbil (Meriones unguiculatus). Lab. Anim. Sci. 1977, 27, 195-203. [PubMed]

164. Samlowski, W.E.; McGregor, J.R.; Bastian, N.R. Identification of Nitric Oxide-Derived EPR Signals in Human Cancers. In Nitric Oxide in Transplant Rejection and Anti-Tumor Defense; Springer: Boston, MA, USA, 1998; pp. 341-352.

165. Lukiewicz, S.; Elas, M.; Raczek, J.; Bratasz, A.; Pajak, S.; Cieszka, K. EPR signals detectable in human tumors. In Nitric Oxide in Allograft Rejection and Anti-Tumor Responces; Springer: Boston, MA, USA, 1998; pp. 353-370.

166. Plonka, P.M.; Plonka, B.K.; Pajak, S.; Lukiewicz, S.J. ESR Studies on the Generation of Nitric Oxide in Rejecting Rat Heart Allografts and In Situ Growing Tumors. Curr. Top. Biophys. 1996, 20, 46-52.

167. Plonka, P.; Plonka, B.; Cieszka, K.; Raczek, J.; Lukiewicz, S. EPR Analysis of Tumor-Host Interactions. In Nitric Oxide in Transplant Rejection and Anti-Tumor Defense; Springer: Boston, MA, USA, 1998; pp. 313-326.

168. Lancaster, J.R.; Hibbs, J.B. EPR demonstration of iron-nitrosyl complex formation by cytotoxic activated macrophages. Proc. Natl. Acad. Sci. USA 1990, 87, 1223-1227. [CrossRef] [PubMed]

169. Plonka, P.; Plonka, B.; Drzewinska, M.; Pajak, S. Accelerated Rejection of Cardiac Allografts and Xenografts in Presensitized Rats and Gerbils. In Nitric Oxide in Transplant Rejection and Anti-Tumor Defense; Springer: Boston, MA, USA, 1998; pp. 205-211.

170. Pustelny, K.; Bielanska, J.; Plonka, P.M.; Rosen, G.M.; Elas, M. In vivo spin trapping of nitric oxide from animal tumors. Nitric Oxide 2007, 16, 202-208. [CrossRef] [PubMed]

171. Gray, J.M.; Pierce, G.B. Relationship Between Growth Rate and Differentiation of Melanoma In Vivo. JNCI J. Natl. Cancer Inst. 1964, 32, 1201-1211. [CrossRef] [PubMed]

172. Grin, C.M.; Kopf, A.W.; Welkovich, B.; Bart, R.S.; Levenstein, M.J. Accuracy in the Clinical Diagnosis of Malignant Melanoma. Arch. Dermatol. 1990, 126, 763. [CrossRef] [PubMed]

173. Chang, M.C.; Hunt, D.M.; Turbyfill, C. High Resistance of Mongolian Gerbils to Irradiation. Nature 1964, 203, 536-537. [CrossRef] [PubMed]

174. Nelson, J.M. Survival Time Response of the Mongolian Gerbil after Total Body Irradiation. Radiat. Res. 1971, 48, 189-198. [CrossRef] [PubMed]

175. Jacobson, A.P.; Sullivan, M.T.; Lutkenhoff, D.W.; Parkinson, W.C.; Overway, D.J. Radioresistance of Mongolian Gerbils. Int. J. Radiat. Biol. Relat. Stud. Phys. Chem. Med. 1977, 31, 265-273. [CrossRef] [PubMed]

176. Suzuki, F.; Nakao, N.; Nikaido, O.; Kondo, S. High Resistance of Cultured Mongolian Gerbil Cells to X-Ray-Induced Killing and Chromosome Aberrations. Radiat. Res. 1992, 131, 290-296. [CrossRef] [PubMed]

177. Brożyna, A.A.; Jóźwicki, W.; Roszkowski, K.; Filipiak, J.; Slominski, A.T. Melanin content in melanoma metastases affects the outcome of radiotherapy. Oncotarget 2016, 7, 17844-17853. [CrossRef] [PubMed]

178. Miller, A.J.; Mihm, M.C. Melanoma. N. Engl. J. Med. 2006, 355, 51-65. [CrossRef] [PubMed]

179. Carlson, J.A.; Ross, J.S.; Slominski, A.; Linette, G.; Mysliborski, J.; Hill, J.; Mihm, M. Molecular diagnostics in melanoma. J. Am. Acad. Dermatol. 2005, 52, 743-775. [CrossRef] [PubMed]

180. Schadendorf, D.; Fisher, D.E.; Garbe, C.; Gershenwald, J.E.; Grob, J.-J.; Halpern, A.; Herlyn, M.; Marchetti, M.A.; McArthur, G.; Ribas, A.; et al. Melanoma. Nat. Rev. Dis. Prim. 2015, 1, 15003. [CrossRef] [PubMed]

181. Lo, J.A.; Fisher, D.E. The melanoma revolution: From UV carcinogenesis to a new era in therapeutics. Science 2014, 346, 945-949. [CrossRef] [PubMed]

182. Schadendorf, D.; Hauschild, A. Melanoma in 2013: Melanoma-The run of success continues. Nat. Rev. Clin. Oncol. 2014, 11, 75-76. [CrossRef] [PubMed] 
183. Shah, D.J.; Dronca, R.S. Latest Advances in Chemotherapeutic, Targeted, and Immune Approaches in the Treatment of Metastatic Melanoma. Mayo Clin. Proc. 2014, 89, 504-519. [CrossRef] [PubMed]

184. Kwong, L.N.; Davies, M.A. Targeted therapy for melanoma: Rational combinatorial approaches. Oncogene 2014, 33, 1-9. [CrossRef] [PubMed]

185. Rajkumar, S.; Watson, I.R. Molecular characterisation of cutaneous melanoma: Creating a framework for targeted and immune therapies. Br. J. Cancer 2016, 115, 145-155. [CrossRef] [PubMed]

186. Nikolaou, V.; Stratigos, A.J. Emerging trends in the epidemiology of melanoma. Br. J. Dermatol. 2014, 170, 11-19. [CrossRef] [PubMed]

187. Stevens, G.; McKay, M.J. Dispelling the myths surrounding radiotherapy for treatment of cutaneous melanoma. Lancet Oncol. 2006, 7, 575-583. [CrossRef]

188. Ballo, M.T.; Ang, K.K. Radiotherapy for cutaneous malignant melanoma: Rationale and indications. Oncology 2004, 18, 99-107. [PubMed]

189. Testori, A.; Rutkowski, P.; Marsden, J.; Bastholt, L.; Chiarion-Sileni, V.; Hauschild, A.; Eggermont, A.M.M. Surgery and radiotherapy in the treatment of cutaneous melanoma. Ann. Oncol. 2009, 20, vi22-vi29. [CrossRef] [PubMed]

190. Foote, M.; Burmeister, B.; Dwyer, P.; Burmeister, E.; Lambie, D.; Allan, C.; Barbour, A.; Bayley, G.; Pullar, A.; Meakin, J.; et al. An innovative approach for locally advanced stage III cutaneous melanoma. Melanoma Res. 2012, 22, 257-262. [CrossRef] [PubMed]

191. Mendenhall, W.M.; Shaw, C.; Amdur, R.J.; Kirwan, J.; Morris, C.G.; Werning, J.W. Surgery and adjuvant radiotherapy for cutaneous melanoma considered high-risk for local-regional recurrence. Am. J. Otolaryngol. 2013, 34, 320-322. [CrossRef] [PubMed]

192. Baker, A.; Camacho, F.; Andrews, G.; Mackley, H. A retrospective analysis of the role of adjuvant radiotherapy in the treatment of cutaneous melanoma. Cancer Biol. Ther. 2016, 17, 1030-1034. [CrossRef] [PubMed]

193. Oliver, D.E.; Patel, K.R.; Switchenko, J.; Parker, D.; Lawson, D.H.; Delman, K.A.; Kudchadkar, R.R.; Khan, M.K. Roles of adjuvant and salvage radiotherapy for desmoplastic melanoma. Melanoma Res. 2016, 26, 35-41. [CrossRef] [PubMed]

194. Kim, Y.J.; Song, S.Y.; Kim, W.; Jeong, S.-Y.; Choi, W.; Je, H.U.; Lee, J.-S.; Choi, E.K. Feasibility of Postoperative Radiotherapy Using Conventional Fractionation for Lymph Node Metastasis from Cutaneous Melanoma. Anticancer Res. 2017, 37, 4239-4246. [CrossRef] [PubMed]

195. Rule, W.G.; Allred, J.B.; Pockaj, B.A.; Markovic, S.N.; DiCaudo, D.J.; Erickson, L.A.; Deming, R.L.; Schild, S.E. Results of NCCTG N0275 (Alliance) - A phase II trial evaluating resection followed by adjuvant radiation therapy for patients with desmoplastic melanoma. Cancer Med. 2016, 5, 1890-1896. [CrossRef] [PubMed]

196. Guadagnolo, B.A.; Prieto, V.; Weber, R.; Ross, M.I.; Zagars, G.K. The role of adjuvant radiotherapy in the local management of desmoplastic melanoma. Cancer 2014, 120, 1361-1368. [CrossRef] [PubMed]

197. Hedblad, M.-A.; Mallbris, L. Grenz ray treatment of lentigo maligna and early lentigo maligna melanoma. J. Am. Acad. Dermatol. 2012, 67,60-68. [CrossRef] [PubMed]

198. Farshad, A.; Burg, G.; Panizzon, R.; Dummer, R. A retrospective study of 150 patients with lentigo maligna and lentigo maligna melanoma and the efficacy of radiotherapy using Grenz or soft X-rays. Br. J. Dermatol. 2002, 146, 1042-1046. [CrossRef] [PubMed]

199. Naganawa, K.; Koto, M.; Takagi, R.; Hasegawa, A.; Ikawa, H.; Shimozato, K.; Kamada, T.; Okamoto, Y. Organizing Committee for the Working Group for Head-and-Neck Cancer. Long-term outcomes after carbon-ion radiotherapy for oral mucosal malignant melanoma. J. Radiat. Res. 2017, 58, 517-522. [CrossRef] [PubMed]

200. Li, W.; Yu, Y.; Wang, H.; Yan, A.; Jiang, X. Evaluation of the prognostic impact of postoperative adjuvant radiotherapy on head and neck mucosal melanoma: A meta-analysis. BMC Cancer 2015, 15, 758. [CrossRef] [PubMed]

201. Karasawa, K.; Wakatsuki, M.; Kato, S.; Kiyohara, H.; Kamada, T. Working Group for Gynecological Tumors. Clinical trial of carbon ion radiotherapy for gynecological melanoma. J. Radiat. Res. 2014, 55, 343-350. [CrossRef]

202. McKenna, J.K.; Florell, S.R.; Goldman, G.D.; Bowen, G.M. Lentigo Maligna/Lentigo Maligna Melanoma: Current State of Diagnosis and Treatment. Dermatol. Surg. 2006, 32, 493-504. [CrossRef] [PubMed] 
203. Tio, D.; van der Woude, J.; Prinsen, C.A.C.; Jansma, E.P.; Hoekzema, R.; van Montfrans, C. A systematic review on the role of imiquimod in lentigo maligna and lentigo maligna melanoma: Need for standardization of treatment schedule and outcome measures. J. Eur. Acad. Dermatol. Venereol. 2017, 31, 616-624. [CrossRef] [PubMed]

204. Strom, T.; Caudell, J.J.; Han, D.; Zager, J.S.; Yu, D.; Cruse, C.W.; Marzban, S.S.; Messina, J.L.; Trotti, A.M.; Sondak, V.K.; et al. Radiotherapy influences local control in patients with desmoplastic melanoma. Cancer 2014, 120, 1369-1378. [CrossRef] [PubMed]

205. Slominski, A.; Zmijewski, M.A.; Pawelek, J. L-tyrosine and L-dihydroxyphenylalanine as hormone-like regulators of melanocyte functions. Pigment Cell Melanoma Res. 2012, 25, 14-27. [CrossRef] [PubMed]

206. Slominski, A.; Zbytek, B.; Slominski, R. Inhibitors of melanogenesis increase toxicity of cyclophosphamide and lymphocytes against melanoma cells. Int. J. Cancer 2009, 124, 1470-1477. [CrossRef] [PubMed]

207. Kinnaert, E.; Morandini, R.; Simon, S.; Hill, H.Z.; Ghanem, G.; Van Houtte, P. The degree of pigmentation modulates the radiosensitivity of human melanoma cells. Radiat. Res. 2000, 154, 497-502. [CrossRef]

208. Barranco, S.C.; Romsdahl, M.M.; Humphrey, R.M. The Radiation Response of Human Malignant Melanoma Cells Grown in Vitro. Cancer Res. 1971, 31, 830-833. [PubMed]

209. Slominski, A.; Ermak, G.; Wortsman, J. Modification of melanogenesis in cultured human melanoma cells. In Vitro Cell. Dev. Biol. Anim. 1999, 35, 564-565. [CrossRef] [PubMed]

210. Brozyna, A.A.; VanMiddlesworth, L.; Slominski, A.T. Inhibition of melanogenesis as a radiation sensitizer for melanoma therapy. Int. J. Cancer 2008, 123, 1448-1456. [CrossRef] [PubMed]

211. Janjetovic, Z.; Brozyna, A.; Tuckey, R.; Kim, T.-K.; Nguyen, M.; Jozwicki, W.; Pfeffer, S.; Pfeffer, L.; Slominski, A. High basal NF-kB activity in nonpigmented melanoma cells is associated with an enhanced sensitivity to vitamin D3 derivatives. Br. J. Cancer 2011, 105, 1874-1884. [CrossRef] [PubMed]

212. Slominski, A.; Good-Snitkoff, G. Dopa inhibits induced proliferative activity of murine and human lymphocytes. Anticancer Res. 1992, 12, 753-756. [PubMed]

213. Shields, C.L.; Kaliki, S.; Furuta, M.; Fulco, E.; Alarcon, C.; Shields, J.A. American joint committee on cancer classification of uveal melanoma (anatomic stage) predicts prognosis in 7731 patients: The 2013 zimmerman lecture. Ophthalmology 2015, 122, 1180-1186. [CrossRef] [PubMed]

214. Shields, C.L.; Kaliki, S.; Cohen, M.N.; Shields, P.W.; Furuta, M.; Shields, J.A. Prognosis of uveal melanoma based on race in 8100 patients: The 2015 Doyne Lecture. Eye 2015, 29, 1027-1035. [CrossRef] [PubMed]

215. Particle Therapy Co-Operative Group (PTCOG) and Particles Newsletter. Available online: http:/ / www. ptcog.com/ (accessed on 17 August 2017).

216. Egger, E.; Zografos, L.; Schalenbourg, A.; Beati, D.; Böhringer, T.; Chamot, L.; Goitein, G. Eye retention after proton beam radiotherapy for uveal melanoma. Int. J. Radiat. Oncol. Biol. Phys. 2003, 55, 867-880. [CrossRef]

217. Gragoudas, E.S.; Goitein, M.; Verhey, L.; Munzenreider, J.; Suit, H.D.; Koehler, A. Proton beam irradiation. An alternative to enucleation for intraocular melanomas. Ophthalmology 1980, 87, 571-581. [CrossRef]

218. Allen, A.M.; Pawlicki, T.; Dong, L.; Fourkal, E.; Buyyounouski, M.; Cengel, K.; Plastaras, J.; Bucci, M.K.; Yock, T.I.; Bonilla, L.; et al. An evidence based review of proton beam therapy: The report of ASTRO's emerging technology committee. Radiother. Oncol. 2012, 103, 8-11. [CrossRef] [PubMed]

219. Gragoudas, E.S.; Goitein, M.; Koehler, A.M.; Verhey, L.; Tepper, J.; Suit, H.D.; Brockhurst, R.; Constable, I.J. Proton irradiation of small choroidal malignant melanomas. Am. J. Ophthalmol. 1977, 83, 665-673. [CrossRef]

220. DeLaney, T.F.; Kooy, M.H. Proton and Charged Particle Radiotherapy; Lippincott Williams \& Wilkins: Philadelphia, PA, USA, 2008; ISBN 978-3-642-00874-0.

221. Sas-Korczynska, B.; Markiewicz, A.; Romanowska-Dixon, B.; Pluta, E. Preliminary results of proton radiotherapy for choroidal melanoma-The Kraków experience. Wspolczesna Onkol. 2014, 18, 359-366. [CrossRef] [PubMed]

222. Romanowska-Dixon, B.; Pogrzebielski, A.; Bogdali, A.; Markiewicz, A.; Swakoń, J.; Olko, P.; Jezabek, M.; Sas-Korczyńska, B.; Pluta, E. Proton beam radiotherapy of uveal melanoma-Preliminary results. Klin. Oczna 2012, 114, 173-179. [PubMed]

223. Verma, V.; Mehta, M. Clinical Outcomes of Proton Radiotherapy for Uveal Melanoma. Clin. Oncol. 2016, 28, e17-e27. [CrossRef] [PubMed]

224. Romanowska-Dixon, B.; Markiewicz, A.; Sas-Korczynska, B.; Medoń, D.; Walasek, T. Evaluation of intraocular proton beam irradiation complications after choroidal melanoma treatment. Klin. Oczna 2016, 4, 289-292. (In Polish) 
225. Kedracka-Krok, S.; Jankowska, U.; Elas, M.; Sowa, U.; Swakon, J.; Cierniak, A.; Olko, P.; Romanowska-Dixon, B.; Urbanska, K. Proteomic analysis of proton beam irradiated human melanoma cells. PLOS ONE 2014, 9, e84621. [CrossRef] [PubMed]

226. Li, M.; Zhang, B.; Sun, B.; Wang, X.; Ban, X.; Sun, T.; Liu, Z.; Zhao, X. A novel function for vimentin: The potential biomarker for predicting melanoma hematogenous metastasis. J. Exp. Clin. Cancer Res. 2010, 29, 109. [CrossRef] [PubMed]

227. Kubicka-Trzaska, A.; Starzycka, M.; Romanowska-Dixon, B.; Morawski, K. Use of indocyanine green for photodynamic therapy of choroidal melanoma-Preliminary report]. Klin. Oczna 2003, 105, 132-135. [PubMed]

228. Campagnoli, T.R.; Medina, C.A.; Singh, A.D. Choroidal melanoma initially treated as hemangioma: Diagnostic and therapeutic considerations. Retin. Cases Brief Rep. 2016, 10, 175-182. [CrossRef] [PubMed]

229. Fabian, I.D.; Stacey, A.W.; Papastefanou, V.; Al Harby, L.; Arora, A.K.; Sagoo, M.S.; Cohen, V.M.L. Primary photodynamic therapy with verteporfin for small pigmented posterior pole choroidal melanoma. Eye 2017, 31,519-528. [CrossRef] [PubMed]

230. Austin, E.; Mamalis, A.; Ho, D.; Jagdeo, J. Laser and light-based therapy for cutaneous and soft-tissue metastases of malignant melanoma: A systematic review. Arch. Dermatol. Res. 2017, 309, 229-242. [CrossRef] [PubMed]

231. Żygulska-Mach, H.; Maciejewski, Z.; Lukiewicz, S.; Iwasiów, B.; Link, E. Clinical Trials on Chemical Radiosensitization of Malignant Melanoma of the Choroid. Ophthalmologica 1979, 178, 194-197. [CrossRef] [PubMed]

(c) 2018 by the authors. Licensee MDPI, Basel, Switzerland. This article is an open access article distributed under the terms and conditions of the Creative Commons Attribution (CC BY) license (http://creativecommons.org/licenses/by/4.0/). 